Summer 7-26-2021

\title{
Gaining Glycemic Control in Patients with Uncontrolled Type 2 Diabetes in Rural Health
}

\author{
Demetric Childs-Hicks
}

d.childshicks@usa.edu

DOI: https://doi.org/10.46409/sr.NZWC3789

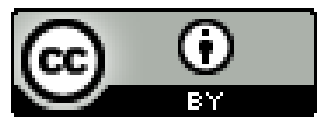

This work is licensed under a Creative Commons Attribution 4.0 License.

Follow this and additional works at: https://soar.usa.edu/scholprojects

Part of the Endocrine System Diseases Commons, Endocrinology, Diabetes, and Metabolism Commons, and the Nutritional and Metabolic Diseases Commons

\section{Recommended Citation}

Childs-Hicks, D. (2021). Gaining Glycemic Control in Patients with Uncontrolled Type 2 Diabetes in Rural Health. [Doctoral project, University of St Augustine for Health Sciences]. SOAR @ USA: Student Scholarly Projects Collection. https://doi.org/10.46409/sr.NZWC3789 
Gaining Glycemic Control in Patients with Uncontrolled Type 2 Diabetes in Rural Health

Demetric Childs-Hicks, MSN, RN, ANP-BC

School of Nursing, University of St. Augustine for Health Sciences

This Manuscript Partially Fulfills the Requirements for the

Doctor of Nursing Practice Program and is Approved by:

Dr. Camille Payne, PhD, RN

Donna P. Stevens, DNP, FNP-C, BC-ADM, CDE

July 26, 2021 


\begin{abstract}
Practice Problem: Diabetes is a significant global healthcare problem. The number of individuals diagnosed with Type 2 Diabetes (T2D) is alarmingly high and the numbers are steadily increasing. Because of various barriers, individuals living in rural communities are at greater risk of having uncontrolled T2D.

PICOT: The PICOT question that guided this project was "Will patients with uncontrolled T2D in rural health have better control of their glucose levels when using telephone or web-based monitoring by healthcare providers than patients with uncontrolled T2D in rural health who do not use technology to achieve glycemic control as evidenced by lower pre-prandial blood glucose levels over 8 weeks?"
\end{abstract}

Evidence: Evidence indicates that implementing telehealth strategies significantly lowers preprandial blood glucose levels in patients with uncontrolled T2D in rural participants.

Intervention: Telemedicine was utilized as an innovative approach to coach and monitor patients in efforts to gain glycemic control. Coaching provided nutritional intake for meal planning, dietary tips to modify diet, and various low-impact exercises to increase physical activity; monitoring motivated patients to keep a daily log of their fasting blood sugars and assessed accountability.

Outcome: The goal was to have a $25 \%$ reduction in fasting blood sugars in participants using the intervention, but findings surpassed that with a $45 \%$ reduction in pre-prandial glucose using telemedicine.

Conclusion: Using telemedicine to gain glycemic control is statistically and clinically significant. This innovative approach not only improves health outcomes, but it increases access to care for those living in rural communities. 


\section{Gaining Glycemic Control in Patients with Uncontrolled Type 2 Diabetes in Rural Health}

As healthcare professionals strive to embrace population health by integrating both clinical and self-management into the quality of care for patients, there is increased expectation that this concept will yield improved patient outcomes (Agency for Healthcare Research and Quality [AHRQ], 2017). Diabetes is a disease that plagues the nation and exists in all demographics. However, those in rural populations have some unique challenges that require immediate action (Advanced Local Media, 2016). The defining problem is uncontrolled Type 2 Diabetes (T2D) in patients at a healthcare facility in Jefferson County, Alabama. T2D is a chronic metabolic condition that usually develops in middle to late adulthood and is characterized by increased levels of sugar in the blood, insulin resistance, and decreased insulin production. Causes of T2D are associated with genetics, environmental and/or behavior risk factors (Olokoba et al., 2012). Unique challenges of those in rural health include limited healthcare providers, healthcare services, transportation, and lack of health insurance.

Overcoming this challenge will lead to improved patient outcomes along with a reduction in cost associated with diabetes management (American Diabetes Association, 2018).

More than 30 million citizens in the United States (US) are affected by diabetes (Center for Disease Control, [CDC], 2018). Poor diabetes control can lead to other unwarranted health conditions (Herman et al., 2018). The problem is patients with uncontrolled T2D in rural Alabama have barriers that inhibit them from achieving optimal control of their glucose levels. The aim of this project was to improve glycemic control as evidenced by lower pre-prandial blood glucose levels by $25 \%$ over 8 -weeks. The purpose of this evidence-based project was to pilot use of telephone or web-based monitoring by healthcare providers in rural Alabama for 
persons with uncontrolled T2D with glycosylated hemoglobin (hgbA1c) levels between 10\% to $14 \%$.

\section{Significance of the Practice Problem}

Diabetes is a globally striking disturbance in healthcare; it affects more than 460 million individuals worldwide (International Diabetes Federation, 2020). The incidence of diabetes climbed worldwide from 11.3 million in 1990 to 22.9 million in 2017 (Lin et al., 2020).

Diabetes is one of the leading causes of death in the US (CDC, 2018). In 2017, diabetes was the 8th leading cause of death in Alabama (CDC, 2018). Individuals living in rural communities with low socioeconomic status are at increased risk for poor diabetes control (World Health Organization [WHO], 2019). More than $10 \%$ of the Jefferson County residents have been diagnosed with diabetes (Advanced Local Media, 2016). This exceeds the National average of 8\% (Alabama Department of Public Health [ADPH], 2010). Approximately 1 in 10 individuals residing in Alabama are diagnosed with diabetes; this is an estimate of nearly 500, 000 residents (ADPH, 2007). According to CDC, there was nearly $13.8 \%$ of Alabama citizens diagnosed with diabetes in 2013. Although this was a significant number of residents, there are thousands remaining who are not aware that they have the disease and rates continue to climb (ADPH, 2015).

There was an approximate $4 \%(5.6 \%$ to $9.7 \%)$ rate increase in the number of citizens diagnosed with diabetes in Alabama from 1990 to 2005 (ADPH, 2007). Individuals with diabetes have 4 times greater chance of dying with heart disease or stroke compared to those who do not have this disease (ADPH, 2015). Poor glycemic control aids in further decline of a patient's health, especially if this exists with other comorbidities (Herman et al., 2018). With uncontrolled 
diabetes, there is a higher risk for stroke, organ failure, heart disease, renal disease, and even death (Herman et al., 2018).

Nationally, diabetes costs the US healthcare systems more than $\$ 327$ billion annually (American Diabetes Association [ADA], 2018) and regionally, Alabama spends approximately \$5 billion dollars on diabetes-related complications (ADA, n.d.). Patients with diabetes have a major impact on the economy. The US faces economic hardship as persons with complications from uncontrolled diabetes accounts for approximately $\$ 9,000$ in indirect costs, not including rooming, of healthcare expenditure per person each year for hospital visits (ADA, n. d.). A valuable percentage of the US mortality rates are attributed to uncontrolled diabetes (ADA, n.d.). Patients need access to telephone or web-based monitoring to have better control of their glucose levels (Mallow et al., 2015). Having this access will help to prevent hospital admissions which improves health and quality of life in the short-term. Over the long-term, having access to telephone or web-based monitoring and improved diabetes control will prevent complications, thereby improving health and quality of life. Cost savings is a benefit of both short-term and long-term benefits.

In the past, payers were unwilling to reimburse for telehealth medicine visits. However, with the onset of a world-wide pandemic of the Novel Coronavirus 19 (COVID-19), payers have waived this rule (Lee et al., 2020). The purpose of this project was to validate the effectiveness of telehealth medicine in the rural health population and to promote the continued use of this method of healthcare moving forward as a system change. This was accomplished, in this project, by evaluating the effectiveness of the telehealth services for those with T2D receiving telehealth services as a beginning to make a system change in the healthcare delivery for rural health patients in Alabama. 


\section{PICOT Question}

The question addressed in this evidence-based project is "Will patients with uncontrolled T2D in rural health (P) have better control of their glucose levels when using telephone or webbased monitoring by healthcare providers (I) than patients with uncontrolled T2D in rural health who do not use technology to achieve glycemic control (C) as evidenced by lower pre-prandial blood glucose levels $(\mathrm{O})$ over 8 weeks $(\mathrm{T})$ ?”

\section{Population}

The population in this evidence-based change project were patients with uncontrolled T2D (age 18 to 65) residing in rural Alabama with glycosylated hemoglobin (hgbA1c) levels between $10 \%$ to $14 \%$. Newly diagnosed patients with T2D (1 year or less) were excluded due to limited data to review. Other exclusions included individuals with terminal illnesses, pregnant women, severe psychiatric illnesses, or addictions, and those with end stage renal, liver, or heart disease (clinicaltrials.gov, 2017). Patients must have had access to a phone, web-based technology, or an active internet connection to attend appointments.

\section{Intervention}

The goal was to assist patients with T2D gain glycemic control is through telephone or web-based monitoring. Previous studies have shown that using this type of technology is an effective modality in helping patients lower their blood glucose levels (Randall et al., 2020).

\section{Comparison Intervention}

Individuals that did not receive the intervention but meet other criteria as those receiving the intervention were the comparison group. Data from those receiving the intervention were compared with data from those who did not receive telehealth for their healthcare. 


\section{Outcome}

Using technology with patients with uncontrolled T2D unveiled the effectiveness of the intervention as patients gained glycemic control as evidenced by lower fasting glucose levels $>25 \%$ (Jeffrey et al., 2019).

\section{Timing}

Over 8 weeks, data was collected (see Appendix F) on the patients' use of technology to lower pre-prandial glucose levels. The glucose results were utilized for review and evaluation to determine if the intervention was effective.

\section{Evidence-Based Practice Framework \& Change Theory}

The process or area requiring change was identified. Individuals employed at the healthcare facility and worked in the endocrinology department were knowledgeable of the impact that diabetes has on the population that they served. They witnessed, firsthand, individuals with amputations, visual declines, and those requiring dialysis because of uncontrolled diabetes (Herman et al., 2018). When communities are plagued with a known health condition, health officials, health care providers, and community leaders are compelled to make changes to yield improved patient outcomes. This institution was forward-thinking and many processes have been put into place to develop telehealth as an emerging practice option prior to the pandemic. A director of telehealth was named. Support staff including a telehealth nurse were hired. Systems changes were implemented to support telehealth services. In the endocrinology department, a case manager was hired to perform telehealth calls (nonreimbursed) to help with coordination of care and to prevent hospital readmission. Following the onset of the pandemic and required quarantine, this institution was quickly able to align other 
systems, processes, standards of care, and to assign personnel to support telehealth on a large scale (Dr. D. Stevens, personal communication, November 22, 2020).

One approach to resolving this epidemic in Alabama was utilizing Johns Hopkins Nursing Evidence-Based Practice (JHNEBP) model. This model utilizes a 3-step method to help guide the decision-making process: practice question, evidence, and translation (PET; hopkinsmedicine.org, n. d.).

\section{Johns Hopkins Nursing Evidence-Based Practice Model}

\section{PICOT Question}

After the problem (uncontrolled diabetes in rural health) had been identified, the next step entailed developing a question that the intervention will unveil or offer a resolution. The question is: Will the use of technology help persons with T2D gain glycemic control? Once the question was established, an interdisciplinary team of champions and stakeholders were identified to assist in the project's implementation phase. Roles and responsibilities were assigned according to everyone's level of expertise. Along with this, a schedule for meetings was established, and deadlines for submitting data determined.

\section{Evidence}

Next, the project manager (PM) provided evidence that supported the recommended intervention (use of technology) to gain glycemic control in patients with uncontrolled T2D living in rural communities. After conducting a literature search on the use of technology and diabetes control, data was summarized and appraised for relevance and quality. After synthesizing the literature, valid evidence was presented that conveyed the significance of using technology to gain glycemic control and the impact it has on patient health outcomes. 


\section{Translation}

After the literature was analyzed, the team determined how this data was incorporated into this organization's practice flow. The team created an action plan and provided instructions for implementing the action plan. Guidelines on the processes for utilizing technology were established. All involved parties, including patients and staff received training on their assigned tasks. Following the implementation, the PM evaluated the effectiveness of the intervention, identified any areas requiring change, notified the team of findings, adjusted as needed, and determined how this data would be disseminated to other clinics within the organization and other community agencies.

\section{Lewin's Change Theory}

While conducting a literature search, the scholar seemed inspired by Lewin's change theory as it offers an outline to scrutinize the process for organizational change. Lewin begins by identifying the need for change, providing strategies to navigate through the process, and suggesting innovative ways to achieve the desired outcome (Burnes, 2004). Lewin recommends using the following steps, unfreezing, moving, and refreezing (Burnes, 2004). This theory will guide the evidence-based project from the initiation phase through the evaluation phase.

The unfreezing phase began by observing the number of patients who were admitted to this hospital due to uncontrolled diabetes. After identifying this as a problem, the PM felt the need to collaborate with potential stakeholders to obtain their perception of the problem and need

for systems change (Burnes, 2004). Next, a review of the way care was delivered was conducted. Findings suggested that there were internal and external factors that affect the delivery of care. Later, the PM conducted an organizational assessment of the healthcare institution to determine 
its mission, vision, and readiness to change. This data offered guidance in identifying an area needing improvement and potential strategies to incorporate change (Moran et al., 2020).

Health care processes involve the activities utilized in caring for patients during a visit as well as in their personal environment. From the moment of diagnosis to prescription protocol, to dietary modification affects how patients with diabetes will respond to this health condition. In the movement phase, patients are encouraged to make behavior modifications to improve their health. Patients who participate and are actively engaged will demonstrate their willingness to move toward making lifestyle changes (Burnes, 2004). Depending on the success of the therapeutic intervention and the patient's response will determine the patient's overall health outcome.

During the refreezing phase, an evaluation of the patients and providers conformation to the 'new' change will be conducted. For these patients, the desired outcome was to have improved glycemic control (Burnes, 2004). The goal was to have fasting blood glucose levels less than $120 \mathrm{mg} / \mathrm{dl}$ in adult patients with diabetes at the end of the eight-week project implementation period (ADA, 2020).

\section{Evidence Search Strategy}

While searching for literature, the task is aimed to identify evidenced-base data to support the implementation of an intervention to lower blood glucose levels in patients with T2D that have poor glycemic control in rural health care. The initial search for evidence-based articles, pertaining to the PICO question began while utilizing the University of St. Augustine for Health Sciences' library search engine. Upon exploration, Gaining Control of Diabetes in Rural Health was the first basic search phrase. Using this search, the following limiting criteria was applied: 
dates from 2015-2020, peer reviewed, full text, available in library collection, and English language.

The first process yielded more than 7,000 results. Then, there was a switch to the advanced search option and the modifier AND was utilized to narrow the search; the limiters remained the same. This time the results produced more than 3,000 results. Later, the scholar utilized the PICO search strategy under the CINAHL complete database using the following phrases: uncontrolled diabetes $(\mathrm{P})$, technology $(\mathrm{I})$, and diabetes control $(\mathrm{O})$ to yield only 3 results. Next, utilizing the CINAHL complete data base with the following Boolean/phrase (technology and diabetes type 2 or control) yielded 1,093,692 results; after applying limitations (the last 5 years, age 19-64, Inpatient and Outpatient, excluded pregnancy, and English language), there were 91 articles found. The age restriction was applied due to the population that has been chosen for the intervention group during the project includes this age group. Pregnancy category was excluded due to this population of individuals will not be included during the intervention process.

Utilizing the Cochrane database of systematic reviews, the scholar incorporated technology glycemic control diabetes as the search phrase to yield 99 results; there was an alternative spelling of glycemic (glycaemic). Another search phrase was using technology to gain glycemic control diabetes yielded 63 results with an alternative spelling of glycemic (glycaemic).

Another database utilized during the literature search was Proquest. The initial filters applied were scholarly journals, last 5 years publication date, and English language. The terminology utilized during the search was technology to gain glycemic control in diabetes type 2 and from this search 3,255 articles were discovered. Using the same filters but changing the 
search phrase to apps to gain glycemic control in diabetes type 2 yielded 419 results. From this literature search, the scholar feels that there is a significant amount of literature to explore the PICO question further.

\section{Evidence Search Results}

During the literature search, the scholar found a plethora of articles that were relevant to the topic; however, due to this massive amount of data, the scholar had to narrow the search to one that is more manageable. After a thorough review of the literature, the scholar narrowed the articles by eliminating those that were not relevant to suffice proceeding with the evidence-based change project.

From CINAHL complete data base, the search yielded 91 articles of which only three articles were found to be significantly relevant to the PICO question. Some of these articles were eliminated as the strength of the evidence was weak or included participants for which the project chooses to exclude. For example, numerous articles were relative to patients with Type 1 diabetes, but the scholar chooses to implement a project that is relative to the reduction of fasting blood sugars in patients with T2D.

Similarly, Cochrane database yielded 63 articles of which only three were considered relevant to the plan to support the use of technology to improve glycemic control in patients with T2D. For example, some of the articles did not produce enough evidence to support the use of technology being an effective modality to reduce blood glucose levels.

On the other hand, Proquest databased produced 419 articles of which only six articles that provided valuable evidence of high quality. Although many of these articles appeared to relate to the chosen intervention, but after reviewing the abstract, many were excluded to 
conclusion of the studies required more studying or effort to prove that the technological intervention would be effective in yielding positive patient outcomes.

After a review of literature was conducted and the exclusion criteria was applied, there were a total of 12 articles that seem beneficial in supporting the use of technology to gain glycemic control in patients with T2D in rural health. The Prisma Model is included to display the search strategy (see Figure 1). Along with the strategic review of literature, the author provides the level and grading of the evidence obtained in the articles using the JHNEBP model (see Figure 2).

\section{Themes with Practice Recommendations}

After a rigorous review and analysis of a plethora of data and its relevance to technology use and diabetes management in rural populations, the following themes were identified: potential barriers for implementation and sustainability (WHO, 2019), potential benefits of diabetes self-management (So \& Chung, 2017; Russell et al., 2017), and exchange of health information between patient and provider (Mallow et al., 2015). The themes identified included those that addressed patient awareness, knowledge, and skills to aid in improving their health outcomes.

\section{Potential Barriers for Implementation and Sustainability}

Potential barriers to the pilot project and to the systems change were evaluated. First, barriers to the pilot project will be discussed. Often, an individual's response to their healthcare needs is the result of lack of understanding or perception of the disease process, limited resources, or access to care (WHO, 2019). Social, economic, and physical factors, also known as determinants of health, affect a person's health outcomes. Determinants of health also impact an individual's perception of "health". Patients living in rural populations are often plagued with 
limited resources and face challenges overcoming these barriers that hinder them from achieving optimal health outcomes (WHO, 2019).

Although seemingly effective, Barker et al. (2016), suggested that technology can be rewarding if patients have access, but without the intervention the recommendation is impertinent. So and Chung (2018) also concurs that use of technology will improve glycemic control in patients with diabetes but recommends cost be considered as this could limit patient's participation with the intervention. Lack of available technology and knowledge of its use limits one's ability to engage in modern interventions that can positively influence their health. Not only does the inability to use technology hinder patients from complying with recommended treatment regimen but lacking proper training regarding technology along with other interventions such as appropriate dietary guidelines required to maintain adequate diabetes control, impairs a patient's capability to take action to manage their diabetes (Peng et al., 2016).

Patients should be provided the necessary training and education on the use of the technology chosen, and the caregiver should make sure that the patients understand what is expected of them. By assessing the patient's level of understanding, the caregiver will ensure that the patient is competent to perform whatever tasks are required in diabetes management. When patients understand the rationale for performing or engaging in an intervention, they are more prone to participate in the activity (Peng et al., 2016).

Although integrating an evidence-based text messaging system along with dietary modifications will be beneficial in diabetes management, rural populations may face technical issues and limited resources that can pose barriers that will hinder the project from being successful (Russel et al., 2017). Despite collective efforts to employ an individual's participation to improve their health outcomes, another barrier exists, noncompliance. Nevertheless, Barker et 
al. (2016), believes use of a telephone intervention can improve consistency as well as replication. Even after being provided the necessary resources, including training and equipment, some patients will not adhere to the recommendations that have been designed for their individualized care. An individual's perception, level of motivation, or satisfaction will predict whether an individual will adopt a given behavior (Peng et al., 2016).

Next, systems barriers will be discussed. When making a system change, many factors should be considered. First is the current state and the need for change. Because of the abrupt need for systems change, the movement to telehealth was embraced. Systems had been put into place already, as discussed, and the transition was made easily. When thinking about advocating for continued use, one of the barriers anticipated is the question as to whether the outcomes will be comparable. The purpose of this systems project is to use the pilot project to show the effectiveness of this modality of care for the chosen population. Discussion of the details of the pilot project will follow in coming paragraphs.

\section{Potential Benefits of Diabetes Self-Management}

Text messaging, use of mobile apps, and telemedicine are all methods of technological interventions proven effective in managing diabetes (So \& Chung, 2017; Russell et al., 2017). Strategically planning to provide these resources to patients in rural populations will assist in diabetes self-management, improved health outcomes, and reduce the burden that uncontrolled diabetes has on rural communities. These innovative approaches to diabetes management not only help lower A1c levels, but also provide access to care for those living in communities with limited access to care and is cost-effective (Mallow et al., 2015; Randall et al., 2020). These interventions are motivational in empowering patients to become active participants in their care. Likewise, Barker et al. (2016) unveiled the significance telephone monitoring/coaching has on 
lowering blood glucose levels using Level 3 high-quality evidence. Although their interventions were not applied to individuals in rural populations, Benson et al. (2019), provides Level 1, Grade-A quality evidence to support use of telemedicine along with a registered dietitian nutritionist $(\mathrm{RDN})$ recommendation and proper medications to lower A1c levels in patients with diabetes.

\section{Exchange of Health Information Between Patient and Provider}

Using mobile devices or telemedicine allows the caregiver and the patient to interact via synchronous communication. This method of rendering health care is especially beneficial to those who lack access to care in rural communities (Mallow et al., 2015). During this exchange, data can be retrieved, shared, and reviewed in real time to allow immediate response by the healthcare provider as well as the patient. For example, a patient having a blood sugar reading of 400 at the time of the interaction between the provider and patient allows the provider to intervene rapidly by offering treatment recommendations (i.e., insulin injection) that can prevent a sentinel event from transpiring. Likewise, Porter et al. (2016), recommends that mHealth should be the gold standard for diabetes management as with modernization, most patients already have this tool readily available to receive, send, and store data.

\section{Practice Recommendations}

Using the JHNEBP model (see Figure 2), a review of literature was narrowed by including Level I-III, Grade A \& B, good quality evidence-based studies to support the project proposal of implementing telephone, or web-based monitoring in patients in rural populations to improve glycemic control in patients living with uncontrolled T2D. As found in previous studies, use of technology is an innovative, cost-effective, positive influence to gain glycemic control in patients with uncontrolled T2D living in rural communities (So \& Chung, 2017; Russell et al., 
2017). One goal of this evidence-based project was for it to be approved, implemented, accepted, and utilized in other rural health centers across the US.

\section{Setting, Stakeholders, and Systems Change}

This evidence-based project will take place at a local hospital, in Southcentral Alabama. This facility is one of the leading academic medical centers in the nation. They have gained honorable recognition as they strive to provide exceptional services to all, but especially to the medically underserved population in this region; this includes individuals with insurance and those without insurance. This organization provides high quality coordinated primary health care services to the local and surrounding counties. The mission and vision for this organization is to remove barriers that prevent patients from receiving health care by providing quality, affordable access to healthcare to meet the physical, mental, social, and emotional needs of the patients they serve.

Implementing evidence-based practice (EBP) change is vital for an organization's continued success (Ehrhart et al., 2014). Organizations must receive buy-in from stakeholders and leadership, colleagues, and be willing to empower them through training opportunities to better prepare everyone for their role (Wrigley, 2020).

Prior to initiating the change project, an assessment of the organization's readiness to change is warranted. By conducting a strengths, weaknesses, opportunities, and threats (SWOT) analysis, the project team can identify areas the organization is doing well in, the areas needing improvement, the progress, and areas that are potentially harmful (Weston, 2018). One of the strengths of this organization included familiarity with and the ease of navigating the electronic health records. Being able to swiftly access data electronically versus scrolling through multiple pages of a paper chart, reduced the amount of time locating information and allowed for more 
time to focus on the patient (Gecomo et al., 2020). Staff being lackadaisical about learning the features of a new process for caring for patients with diabetes is one of their weaknesses. Some individuals become complacent with current conditions or systems and are hesitant to change. A summary of the organization's SWOT analysis can be found in Appendix E.

After the SWOT was conducted, identification of potential solutions was performed. Along with that, a leadership assessment was conducted to identify areas of strengths of employees and place them in positions they are most efficient. In addition, a description of the costs and benefits were conducted while preparing a plan for recommendations. Performing a cost analysis provided details of what the expected expenses would be. For instance, there was a need for additional staff during training on the new system's change. Allotting for overtime was not necessary during this process. The cost of supplies to be purchased, i.e., signage, copies, ink, etc., along with the cost of salaries for those spending additional hours reviewing project information or for those conducting trainings was considered.

Staff responsible for project implementation and sustainability was identified. Collaboration with the following members of the quality team and key stakeholders included the following individuals: Glycemic Task Force (GTF) Team (Director for the Division of Endocrinology (DDE), Lead Nurse Practitioner (LNP), Pharmacist(s), Case Manager (CM), Quality Coordinator (QC), Diabetes Education Coordinator (DEC), Financial Officer (FO), Information Technology (IT) staff), patient liaison, social service, PM, and a community advocate. The PM, CM, and LNP were responsible for retrieving and analyzing data; a statistician was not required; therefore, cost was minimal. Due to the limited expense and appropriate training, the organization is able to sustain this project. Developing a strategic plan 
that created an atmosphere with the least disruption as the organization undergoes this change project was the main objective.

\section{Implementation Plan with Timeline and Budget}

JHNEBP model guided the PM in identifying a practice problem that was crippling the rural communities in Alabama. After identifying the problem that appeared most taunting to the organization and the patient population serviced, the PM began an immediate search for evidence to support a resolution of uncontrolled diabetes in rural communities and the impact it has on their health outcomes.

The purpose of this project was to assist patients in gaining control of their diabetes by lowering their fasting blood glucose levels by $25 \%$ which further improves their overall health outcomes (Herman et al., 2018). In effort to gain control of diabetes in rural Alabama, healthcare providers at a local hospital in Southcentral Alabama conducted weekly telephone or telemedicine monitoring and coaching utilizing the data collection tool (see Appendix G), the LMC Diabetes Skills, Confidence, \& Preparedness Index (SCPI; Mbuagbaw et al., 2017) tool (see Appendix G) and coaching interventions (see Appendix H) to lower fasting blood glucose levels in adults with diabetes over 8 weeks. The goal was to gain glycemic control in patients with diabetes by lowering pre-prandial blood glucose levels to below $120 \mathrm{mg} / \mathrm{dl}$. When this is achieved, patients will have improved health outcomes (Jeffrey et al., 2019). This aligned with the organization's mission to have improved patient outcomes. Implementing technological strategies along with pharmacological and behavioral interventions assisted patients in lowering their blood glucose level. Making frequent contacts with these patients also added to their compliance (Benson et. al., 2019). Using Lewin's change model, the PM was able to assess the organization's structure (leadership and organizational assessments) to identify key stakeholders 
and champions whose qualities were believed to add value to the project by sharing their levels of expertise and work ethic (Moran et al., 2020). Also, the organizational assessment supported the organization's readiness to change. The objectives for this project included identifying the impact that lower fasting blood glucose has on a patient's health outcome; demonstration of how telephone/web-based monitoring help patient's gain control of their fasting blood sugar; identifying the metrics that demonstrates the effectiveness of the intervention.

\section{Project Plan}

For this project, the CM provided the PM with a prospective sample of the telehealth population from the system-generated consults that she received. From this list, the PM shared the participant's contact information and demographics with the providers along with the data collection tool (see Appendix G), coaching interventions (see Appendix H), and the SCPI tool (Mbuagbaw et al., 2017). This tool provided an overview of the patient's responses to selfmanagement skills. Data collected was employed to show the effectiveness of utilizing telehealth as a modality of healthcare delivery for those with T2D in rural health. This method of evaluation was used as there is a reliable and valid tool in place for screening, a standardized programmatic approach to evaluation of diabetes control, and data accessibility. The goal was to utilize this project to promote continued use of telehealth as a modality for delivery of care across the health system.

From the system-generated consult, participant's meeting the criteria that had been previously established, were screened for those living in rural communities. The CM, and PM identified patients with diabetes whose glycosylated hemoglobin (A1c) level is between $10 \%$ to $14 \%$. Patients were provided information regarding the project and any questions that they had were answered. Next, the CM compiled a spreadsheet for the health care provider (nurse 
practitioner, physician assistant, or medical doctor) to have prior to making telephone/telemedicine contact with the patient. The spreadsheet included pertinent lab values (including most recent blood sugar and A1c results), demographics, vital signs, and method of contact (via the call or telemedicine).

After participants were identified, they received new glucose monitors with testing supplies, glucose monitoring logs, activity logs with low-impact exercises, pedometers, and nutritional handouts with foods to avoid/include in their daily meal planning for the next 60 days. The patients and staff received education regarding the project's purpose and desired outcomes 1 week prior to starting the project. The provider conducted follow-up with these patients on weekly telephone calls or via telemedicine to assess their nutritional intake, daily activity, including steps per day and fasting blood glucose levels. The patients received these contacts weekly until the project ended. When conducting telephone/telemedicine monitoring the provider provided positive feedback to encourage patient to continue to strive to improve the glycemic control by lowering their fasting glucose levels. Coaching (see Appendix H) included behavior modification that incorporated increased physical activity and dietary modifications.

Evidence unveiled that the use of the telephone or internet to communicate to patients helps motivate self-care management, improve provider-patient relationships as well improved patient outcomes (So \& Chung, 2017; Russell et al., 2017). The goal was to have fasting blood glucose levels less than $120 \mathrm{mg} / \mathrm{dl}$ in adult diabetic patients (American Diabetes Association, 2020). The average blood glucose was obtained by the PM from the patient's electronic health record.

As staff proceeded with the intervention(s), there was continuous patient, family, and staff education, feedback, and evaluation to ensure that appropriate data was collected, and the 
team remained on track with the allotted timeframe for the project. Random audits took place by the PM to ensure compliance of staff by noting if they are remaining faithful to the proposed plan. Individual feedback was provided to staff to enhance performance as well as provide group feedback. Within 8 weeks, patients with diabetes whose A1c(s) was between $10 \%-14 \%$ had at least a $25 \%$ reduction in their pre-prandial blood glucose level as a desired outcome.

The cost for treatment, cost savings, percent of staff trained on the use of technology and the percent of staff that adheres to the practice recommendations were obtained from the quality reports provided by the QC during the defined time frame outlined.

\section{Project Timeline and Budget}

Prior to initiating the project, the PM gained approval from the evidence-based practice review committee (EPRC) at the University of St. Augustine for Health Sciences and the chair for the department of endocrinology from the facility that the project took place. After obtaining approval, the PM identified key stakeholders (DNP Student-PM, Preceptor, GTF, patient liaison, social service, QC, and a community advocate) and organized a meeting with them. During this meeting, the PM presented the project plan (including the budget) and the project scope (see Table 1). The budget included expenditure for part-time staff and printing supplies; through collaboration with the team and community resources, the goal was to attain donations from various vendors for diabetes testing supplies and donations from one of the state organizations making strides to overcome uncontrolled diabetes in rural communities.

Roles and responsibilities were assigned, and the timeline and budget presented were approved. Once key stakeholders were recruited, collaboratively, they established a team of champions that were active during the implementation phase of the project and remained valuable assets to the project's success. Next, informational technology and protocols were 
developed along with obtaining necessary equipment and supplies. After champions were identified, staff education took place. The PM provided one-on-one training with each provider participating in the project. This included reviewing the SCPI (see Appendix G) with information that was collected as well as recommended nutritional support and physical activities that were encouraged. Following the identification of champions, the CM/PM obtained permission from patients that e willing to participate in the project (see Appendix F).

\section{Results}

To determine the relevance and magnitude of change that this project has on diabetes control in rural populations, a critical examination of the data that has been collected is vital. The evaluation process included a systematic approach to assess the impact that the intervention had on pre-prandial blood glucose levels in patients living with T2D in rural communities (Moran et al., 2020). This process included identifying, monitoring, and measuring the goals and outcomes that had been established. In addition, during the evaluation phase, a depiction of the effectiveness of the strategies, tools, or resources that were utilized was presented.

During the project, the $\mathrm{PM} /$ preceptor monitored the individuals implementing the intervention process daily during the first week, then weekly until the end of the project for accuracy of the data collection process. Data was collected at the onset of the intervention, then at day 7 , then weekly thereafter until the conclusion of the project.

The PM, preceptor, and CM reviewed the sheets that were titled Data Collection Tool for Evaluation and the results from the $S C P I$ in the patients' medical records as well as the providers documentation during the call/telemedicine visits. After data had been analyzed, the PM and preceptor determined that the intervention impacted the change in the measured variables. 
To ensure fidelity and accuracy of the data collected, standardized, and validated tools were utilized to obtain outcome data. The tools utilized included glucose monitors, EHR, Data Collection Tool for Evaluation (Appendix D), Coaching Interventions (Appendix H), and the SCPI (Appendix G) for provider's use during the call or telemedicine visit. Mbuagbaw et al. (2017) unveiled the integrity of the internal consistency of the subscales of the SCPI (intraclass correlation between 0.83 and 0.88$)$ and retest reliability after 6 months $(r=0.48 ; p<0.01)$. The Coaching Interventions (Appendix H) were abbreviated interventions that incorporated data from AADE7 Self-Care Behaviors and Telehealth Diabetes Screening/Assessment tools (Association of Diabetes Care \& Education Specialists [ADCES], 2020; American Health Information Management Association [AHIMA], 2018). Data extracted from the EHR was decoded, stored, and locked in a file cabinet, and later shredded; the team strived to only use decoded electronic files to mitigate the likelihood of a type of electronic breach.

After all the data was reviewed and organized, data analyzation utilized Intellectus Statistic Software package. To determine the statistical significance of the results and clinical significance of the intervention, a $p$ value of less than 0.05 was utilized. Since there was not a normal distribution based on the results of a Shapiro-Wilk test, a two-tailed Wilcoxon Signed Rank test was conducted to examine whether there was a significant difference between the fasting blood sugar (FBS) at the start of the intervention and at the end of the intervention. The two-tailed Wilcoxon signed rank test is a non-parametric alternative to the paired samples t-test and does not share its distributional assumptions (Intellectus Statistics, 2021; Conover \& Iman, 1981).

The results of the two-tailed Wilcoxon signed rank test were significant based on an alpha value of $0.05, \mathrm{~V}=36.00, \mathrm{z}=-2.52, \mathrm{p}=.012$. This indicated that the differences between 
FBS pre and post intervention are not likely due to random variation. The median of FBS preintervention $(\mathrm{Mdn}=194.00)$ was significantly larger than the median of FBS post intervention $(\mathrm{Mdn}=107.50)($ Intellectus Statistics, 2021). Figure 3 presents a boxplot of the ranked values of fasting blood sugar pre and post intervention indicating that the intervention was successful. Based on these findings, use of telemedicine was effective in achieving the outcome goal of lowering pre-prandial glucose levels in patients with uncontrolled T2D in rural health.

Descriptive statistics demonstrated the frequency and percentages of the demographic data presented. Figure 4 includes a table that represent data analysis of the variables included in the project. There is an equal $(50 \%)$ distribution of male $(n=4)$ and females $(n=4)$; figure 4 shows an average age of $48.50(\mathrm{SD}=16.38)$. Over 8 weeks, the average fasting glucose was $155.12(\mathrm{SD}=19.10)$.

Because the goal was to improve glycemic control for the desired patient population using telemedicine, the risk of harm was minimal, therefore, expedited review from the University of St. Augustine for Health Sciences EPRC was expected. The patients were required to communicate via telephone or through the internet, whichever they were competent in using; this is considered minimal or no harm. If patients were not able to utilize either of the chosen interventions, they were excluded from the project. Whenever there is minimal risk to subjects, often institutional review board (IRB) approval is not warranted (Gandhi, 2017). When projects appear to provide substantial evidence that the desired outcomes will improve the standards of care, a quick review, and a waiver may be granted (Gandhi, 2017). “Our organization (University of Alabama at Birmingham, hospital) has an Institutional Review Board (IRB). However, quality improvement projects or evidence-based projects are exempt from review by the IRB. If, however, in the future, you wish to disseminate the information gained from the project, a review 
will be required" (Dr. D. Stevens, preceptor and Dr. F. Ovalle, Director of the Department of Endocrinology, personal communication, January 20, 2021).

Data anonymization was incorporated as an extra level of protection to ensure that confidentiality was maintained (Vokingeret al., 2020). When collecting data from the patients during the telehealth call, decoding techniques were used to capture valuable information while using unique patient identifiers to keep their information confidential. In all studies, there is potential for breach of patient privacy. Extra precautions were taken to adhere to Health Insurance Portability and Accountability Act (HIPAA) regulations.

\section{Impact}

Using technology via telemedicine has been an effective approach in accommodating patients to gain control of their diabetes as evidenced by lower fasting blood glucose levels over eight weeks. With use of the intervention, the desired outcome was to have a $25 \%$ reduction in fasting blood glucose levels; the intervention was effective as evidence by exceeding that goal with a $45 \%$ reduction in fasting blood sugars.

Patients who are engaged in self-care are more likely to be successful. However, they often needed educational support and adjustments in medical management to aid in their success (Association of Diabetes Care \& Education Specialists, 2020). Allowing patients to have access to monitoring and coaching via various modalities that vary from the traditional 'brick and mortar,' increases the likelihood of compliance with recommended therapeutic interventions. Along with that intervention, patients may benefit from evaluating the A1c levels over a 90-day period in addition to pre-prandial blood glucose levels over eight weeks to provide a more concreate measurement of glycemic management and control. 
The advantages of using telehealth includes convenience, cost-savings, and increased access to care. Eliminating travel to and from the provider often eliminates the stress of finding transportation for those who have limited resources, and it also saves on the cost of travel including fuel, meals, and other associated costs such as parking fees. Those in rural areas may not have a provider or the provider may not have the resources or availability to spend the amount of time necessary to validate the patient's knowledge and skills. Patients with uncontrolled diabetes often present with other medical problems that need attention and limitations in time are often barriers to providing attention to the intricacies of diabetes management.

Limitations of the project included a small number of participants and the availability of technology or internet, and the need for standardized evaluation of overall glycemic control. In addition, tracking costs savings for patients and for the facility were not incorporated into the project, but could be a tool used to justify the addition of a permanent position in this role. Thirty-two participants agreed to participate in the project; however, as time progressed, many of the participants failed to keep their scheduled appointment times for monitoring and coaching as agreed upon. Eight participants completed the project as designed. Results of data collected were significant to demonstrate the effectiveness of the intervention. Another limitation was the availability of the desired technology. Initially, participants were more favorable of telemedicine visits using web-based technology, but, prior to the end of the project, the participants utilized telephone contact as the preferred modality for visits. While telephone visits are appropriate for most visits, video availability ensures that insulin administration skills are appropriate. Using the fasting glucose as a measure glycemic control is helpful but may not adequately assess glycemic 
control. Use of the standardized measure of glycemic control, the hemoglobin Alc level, would be a more accurate way of assessing glycemic management going forward.

To ensure sustainability over time, recommendations are that a permanent position for a provider/diabetes care manager who will report to the Inpatient Glycemic Team NP group be created. This person will continue to contact patients via telemedicine while using the recommended guidelines, to improve glycemic control in patients with uncontrolled diabetes in rural communities, prevent complications, decrease emergency room visits, and decrease hospital admissions. The diabetes care manager will be able to refer patients that need to be seen by a provider to the Diabetes Bridge Clinic to have a telehealth visit as an outpatient. If needed, the patient can be seen in the clinic within one week of their referral. This system will ensure that patients have access to care and avoid unwarranted emergency room visits.

Telemedicine allows patients to overcome barriers that previously prevented them from accessing care, especially those in rural populations and improve patient outcomes. Cost savings will be realized in the prevention of diabetes-related complications and the prevention of the use of emergency room visits for healthcare and prevention of hospital admissions.

\section{Dissemination Plan}

After the findings were analyzed and recorded, it was necessary to determine the desired audience to share this information with. Prior to sharing the data with the team and other stakeholders, peer reviews of the project results will be conducted. Disseminating data from an evidence-based practice change project is an epitome of a strategic plan to improve health outcomes in underserved populations.

Initially, the PM created a PowerPoint presentation to share with the following stakeholders at the central office board room of the hospital in Alabama during the monthly GTF 
meeting. The stakeholders included the GTF Team, patient liaison, social service, quality coordinator, PM, and a community advocate. Next, the presentation will be presented at the Learning Management Series (LMS) at a Federally Qualified Health Center (FQHC) in Selma, Alabama. In addition, the project will be presented at the following regional symposiums: Alabama Primary Health Care Association (APHCA), Nurse Practitioner Alliance of Alabama, and Alabama State Nurses Association. Sharing these findings will allow others to incorporate these findings into their practice or programs to improve their patient's quality of care. For publication, the PM will submit the manuscript to American Diabetes Association or International Journal of Diabetes and Clinical Research. Reasoning for submission to these journals is to share updated relevant data that can assist other scholars in their efforts to improve glycemic control in diabetic patients, especially in rural communities.

\section{Conclusion}

Technology is one of the emerging avenues used as an adjunct to traditional medicine to provide high-quality healthcare (Rush et al., 2018). This project aimed to demonstrate the effectiveness of telephone or web-based monitoring on gaining glycemic control in patients with uncontrolled T2D living in rural populations.

High quality data suggested that there is significant evidence to support implementing telephone or web-based monitoring in patients at the Endocrinology Department in Southcentral Alabama. Patients with T2D will had improved pre-prandial blood glucose levels and overall improvement of glucose management. Using an interdisciplinary approach, healthcare providers actively participated in helping patients achieve their glycemic goals. When incorporating technological interventions along with routine diabetes care, patients had an improvement in 
their overall health. This aligns with the organization's mission to provide quality patient care while improving patient outcomes (UAB Health System, 2020). 


\section{References}

Agency for Healthcare Research and Quality (2017). About the national quality strategy. https://www.ahrq.gov/workingforquality/about/index.html\#aims

Alabama Department of Public Health (2007). Alabama resource directory 2007. http://www.adph.org/diabetes/assets/diabetesresdir.pdf

Alabama Department of Public Health (2010). Diabetes in Alabama. https://adph.org/diabetes/assets/DiabetesinALReport09.pdf

Alabama Department of Public Health (2015). Alabama diabetes resource directory 2015. https://www.alabamapublichealth.gov/diabetes/assets/AL_Diabetes_Resource_Directory - 11.25.2015.pdf

Advanced Local Media (2016). 6 of the 10 most diabetic counties in US are in Alabama. https://www.al.com/news/2016/10/6_of_the_10_most_diabetic_coun.html

American Diabetes Association (2018). Economic costs of diabetes in the U.S. in 2017. Diabetes Care, 41(5), 917-928. https://doi.org/10.2337/dci18-0007

American Diabetes Association (n. d.). The burden of diabetes in Alabama. http://main.diabetes.org/dorg/PDFs/Advocacy/burden-of-diabetes/alabama.pdf

American Health Information Management Association (2018). Integrating diabetes guidelines into a telehealth screening tool. https://ibrary.ahima.org/doc?oid=301174\#.YB1RbuhKg2z

Association of Diabetes Care \& Education Specialists (2020). Resources for people living with diabetes: AADE7 self-care behaviors. https://www.diabeteseducator.org/living-withdiabetes/aade 7-self-care-behaviors 
Barker, K., Mallow, J., Theeke, L., \& Schwertfeger, R. (2016). A telehealth rural practice change for diabetes education and management. The Journal for Nurse Practitioners, 12(16), pp. e225-e229. Retrieved from https://doi.org/10.1016/j.nurpra.2016.01.015

Benson, G. A., Sidebottom, A., Hayes, J., Miedema, M. D., Boucher, J., Vacquier, M., Sillah, A., Gamam, S., \& VanWormer, J. J. (2019). Impact of ENHANCED (diEtitiaNs Helping pAtieNts CarE for Diabetes) telemedicine randomized controlled trial on diabetes optimal care outcomes in patients with T2D. Journal of the Academy of Nutrition and Dietetics, 119(4), 585-598. doi: 10.1016/j.jand.2018.11.013

Burnes B. (2004). Kurt Lewin and the planned approach to change: A re-appraisal. Journal of Management Studies, 41(6), 977-1002. https://doi.org/10.1111/j.14676486.2004.00463.x

Center for Disease Control (2018). National diabetes statistics report. Retrieved September 16, 2020 from https://www.cdc.gov/diabetes/data/statistics/statistics-report.html

Center for Disease Control (2020). Diabetes meal planning. https://www.cdc.gov/diabetes/managing/eat-well/meal-plan-method.html

ClinicalTrials.gov (2017). Prospective study on diabetes mellitus and its complication in newly diagnosed adult patients $(G D C)$. https://clinicaltrials.gov/ct2/show/NCT01055093

Conover, W. J., \& Iman, R. L. (1981). Rank transformations as a bridge between parametric and nonparametric statistics. The American Statistician, 35(3), 124-129. https://doi.org/10.1080/00031305.1981.10479327

Ehrhart, M. G., Aarons, G. A., \& Farahnak, L. R. (2014). Assessing the organizational context for EBP implementation: The development and validity testing of the Implementation Climate Scale (ICS). Implementation Science, 9, 157. https://doi.org/10.1186/s13012- 
014-0157-1. https://implementationscience.biomedcentral.com/articles/10.1186/s13012014-0157-1

Gandhi, T. (2017). 5 Tips for turning QI projects into research. Institute for health care improvement. http://www.ihi.org/communities/blogs/five-tips-for-turning-qi-projectsinto-research

Gecomo, J. G., Klopp, A., \& Rouse, M. (2020). Implementation of an evidence-based electronic health record (EHR) downtime readiness and recovery plan. Online Journal of Nursing Informatics, 24(1), 5.

Herman, W. H., Braffett, B. H., Kuo, S., Lee, J. M., Brandle, M., Jacobson, A. M., Prosser, L. A., \& Lachin, J. M. (2018). What are the clinical, quality-of-life, and cost consequences of 30 years of excellent vs. poor glycemic control in type 1 diabetes? Journal of Diabetes and Its Complications, 32(10), 911-915. https://doi.org/10.1016/j.jdiacomp.2018.05.007

Intellectus Statistics [Online computer software]. (2021). Intellectus Statistics. https://analyze.intellectusstatistics.com/

International Diabetes Federation (2020). About diabetes: Diabetes facts \& figures. https://www.idf.org/aboutdiabetes/what-is-diabetes/facts-figures.html

Jeffrey, B., Bagala, M., Creighton, A., Leavey, T., Nicholls, S., Wood, C., Longman, J., Barker, J., \& Pit, S. (2019). Mobile phone applications and their use in the self-management of T2D mellitus: A qualitative study among app users and non-app users. Diabetology \& Metabolic Syndrome, 11(1), 1-17. doi10.1186/s13098-019-0480-4

John Hopkins Medicine (n. d.). Johns Hopkins nursing evidence-based practice model. https://www.hopkinsmedicine.org/evidence-basedpractice/ijhn_2017_ebp.html\#: :text=The\%20Johns\%20Hopkins\%20Nursing\%20Eviden ce,guide\%20individual\%20or\%20group $\% 20$ use. 
Lee, N. T., Karsten, J., \& Roberts, J. (2020). Removing regulatory barriers to telehealth before and after COVID-19. Brookings: John Lock Foundation, 1-23. https://www.brookings.edu/wp-content/up----loads/2020/05/Removing-barriers-totelehealth-before-and-after-COVID-19_PDF.pdf

Lin, X., Xu, Y., Pan, X., Xu, J., Ding, Y., Sun, X., Song, X., Ren, Y., \& Shan, P. (2020). Global, regional, and national burden and trend of diabetes in 195 countries and territories: an analysis from 1990 to 2025. Scientific Reports, 10(1), 14790. doi:10.1038/s41598-02071908-9.

Mallow, J. A., Theeke, L. A., Barnes, E. R., Whetsel, T., \& Mallow, B. K. (2015). Using mHealth tools to improve rural diabetes care guided by the chronic care model. Online Journal of Rural Nursing Health Care, 14(1), 43-65. doi: 10.14574/ojrnhc.v14i1.276

Mbuagbaw, L., Aronson, R., Walker, A., Brown, R. E., \& Orzech, N. (2017). The LMC skills, confidence \& preparedness index (SCPI): development and evaluation of a novel tool for assessing self-management in patients with diabetes. Health and Quality of Life Outcomes, 15(27). https://doi.org/10.1186/s12955-017-0606-Z

Moran, K., Burson, R., \& Conrad, D. (Eds). (2020). The doctor of nursing practice project: A framework for success (3rd ed.). Jones \& Bartlett Learning.

Olokoba, A. B., Obateru, O. A., \& Olokoba, L. B. (2012). T2D mellitus: A review of current trends. Oman Medical Journal, 27(4), 269-273. doi:10.5001/omj.2012.68

Pawlak, J., Ito, R., Cahill, C., \& Sweatt, M. (2019). Hemoglobin A1c testing and diabetes management. MLO: Medical Laboratory Observer, 51(1), 12-16.

Porter, J., Huggins, C. E., Truby, H., \& Collins, J. (2016). The effect of using mobile technology-based methods that record food or nutrient intake on diabetes control and 
nutrition outcomes: A systematic review. Nutrients, 8(12), 815. doi:

http://dx.doi.org/10.3390/nu8120815

Randall, M. H., Haulsee, Z. M., Zhang, J., Marsden, J., Moran, W. P., \& Kirkland, E. B. (2020). The effect of remote patient learning on the primary care clinic visit frequency among adults with T2D. International Journal of Medical Informatics, 143. https://doi.org/10.1016/j.ijmedinf.2020.104267

Rush, K. L., Hatt, L., Janke, R., Burton, L., Ferrier, M., \& Tetrault, M. (2018). The efficacy of telehealth delivered educational approaches for patients with chronic diseases: A systematic review. Patient Education and Counseling, 101(8):1310-1321. doi: 10.1016/j.pec.2018.02.006

Russell, N. M., Vess, J., Durham, C., \& Johnson, E. (2017). Text-Messaging to Support Diabetes Self-Management in a Rural Health Clinic: A Quality Improvement Project. Online Journal of Nursing Informatics, 21(2), 9-1.

So, C. F. \& Chung, J. W. (2017). Telehealth for diabetes self-management in primary healthcare: A systematic review and meta-analysis. Journal of Telemedicine and Telecare, 24 (5), pp. 356-364. https://doi.org/10.1177/1357633X17700552

TemplateLab (n.d.). 40 powerful SWOT analysis templates \& examples. https://templatelab.com/swot-analysis-templates/

Vokinger, K. N., Stekhoven, D. J., \& Krauthammer, M. (2020). Lost in anonymization - A data anonymization reference classification merging legal and technical considerations. Journal of Law, Medicine \& Ethics, 48, 228-231. doi:10.1177/1073110520917025 
Welch, W. A., Strath, S. J., Brondino, M., Walker, R., \& Swartz, A. M. (2019). Durationresponse of light-intensity physical activity and glucose dynamics in older adults. Journal of Physical Activity \& Health, 16(1), 37-42.

Weston, B. (2018). Your first step toward business growth: SWOT analysis. https://www.score.org/blog/your-first-step-toward-business-growth-swot-analysis

World Health Organization. (2019). Social determinants of health. https://www.who.int/social_determinants/sdh_definition/en/

Wrigley, C., Nusem, E., \& Straker, K. (2020). Implementing design thinking: Understanding organizational conditions. California Management Review, 62(2), 125-143. https://doi.org/10.1177/0008125619897606 
Table 1: Budget

\begin{tabular}{|l|l|l|l|}
\hline EXPENSES & & REVENUE & \\
\hline \multicolumn{1}{|c|}{ Direct } & Billing & $\$ 5000$ \\
\hline Staff \& Patient Training & $\$ 2000$ & & \\
\hline $\begin{array}{l}\text { Supplies (Pedometers, Glucose } \\
\text { Monitors/Testing Supplies) }\end{array}$ & $\begin{array}{l}\text { Donated } \\
\text { by } \\
\text { Vendors }\end{array}$ & Institutional Budget Support & \\
\hline $\begin{array}{l}\text { Ink/Paper for Printing Flyers and } \\
\text { Nutritional Education }\end{array}$ & $\$ 500$ & & \\
\hline & $\begin{array}{l}\text { Provided } \\
\text { by USA }\end{array}$ & & \\
\hline SPSS system & $\$ 5000$ & & \\
\hline $\begin{array}{l}\text { Part-time staff during } \\
\text { implementation }\end{array}$ & & & \\
\hline & & & \\
\hline Indirect & $\$ 7500$ & Total Revenue & \\
\hline Overhead & & & \\
\hline Total Expenses & & & \\
\hline Net Balance & & & \\
\hline
\end{tabular}


Table 2: Variables

\begin{tabular}{|c|c|c|c|c|c|c|}
\hline & $\begin{array}{l}\text { Variable } \\
\text { Name }\end{array}$ & $\begin{array}{l}\text { Variable } \\
\text { Description }\end{array}$ & $\begin{array}{l}\text { Data } \\
\text { Source }\end{array}$ & $\begin{array}{l}\text { Possible } \\
\text { Range of } \\
\text { Values }\end{array}$ & $\begin{array}{l}\text { Level of } \\
\text { Measurement }\end{array}$ & $\begin{array}{l}\text { Time Frame } \\
\text { for } \\
\text { Collection }\end{array}$ \\
\hline \multirow[t]{5}{*}{ Population } & Patient ID & $\begin{array}{l}\text { Unique } \\
\text { Assigned } \\
\text { Identification } \\
\text { number by } \\
\text { Project Manager }\end{array}$ & $\begin{array}{l}\text { Data } \\
\text { Collection } \\
\text { Tool (DCT) }\end{array}$ & N/A & Text & $\begin{array}{l}\text { Onset of } \\
\text { Intervention }\end{array}$ \\
\hline & Gender & Gender & $\begin{array}{l}\text { Electronic } \\
\text { Health Record } \\
\text { (EHR) }\end{array}$ & $\begin{array}{l}1=\text { female } \\
0=\text { male }\end{array}$ & Nominal & $\begin{array}{l}\text { Onset of } \\
\text { Intervention }\end{array}$ \\
\hline & Race & Race & EHR & $\begin{array}{l}\text { 1=African } \\
\text { American } \\
\text { 2=Caucasian } \\
\text { 3=Hispanic } \\
\text { 4=Other }\end{array}$ & Nominal & $\begin{array}{l}\text { Onset of } \\
\text { Intervention }\end{array}$ \\
\hline & Weight & $\begin{array}{l}\text { Weight } \\
\text { Obtained at the } \\
\text { Start of the } \\
\text { Project }\end{array}$ & EHR & $85-350 \mathrm{lbs}$ & Continuous & $\begin{array}{l}\text { Onset of } \\
\text { Intervention }\end{array}$ \\
\hline & Age & $\begin{array}{l}\text { Participants Age } \\
\text { at the Beginning } \\
\text { of the Project }\end{array}$ & EHR & $18-65$ & Continuous & $\begin{array}{l}\text { Onset of } \\
\text { Intervention and }\end{array}$ \\
\hline Event & $\begin{array}{l}\text { Hyperglycemic } \\
\text { Episodes }\end{array}$ & $\begin{array}{l}\text { The Number of } \\
\text { Elevated Blood }\end{array}$ & DCT & $0-10$ & Continuous & $\begin{array}{l}\text { Onset of } \\
\text { Intervention and }\end{array}$ \\
\hline
\end{tabular}




\begin{tabular}{|c|c|c|c|c|c|c|}
\hline & & $\begin{array}{l}\text { Glucose } \\
\text { Readings }\end{array}$ & & & & \\
\hline & $\begin{array}{l}\text { Fasting Blood } \\
\text { Sugar }\end{array}$ & $\begin{array}{l}\text { Pre-prandial } \\
\text { Blood Glucose } \\
\text { Reading }\end{array}$ & $\begin{array}{l}\text { Glucose } \\
\text { Monitoring } \\
\text { Log }\end{array}$ & $60-375 \mathrm{mg} / \mathrm{dL}$ & Continuous & $\begin{array}{l}\text { Weekly, End of } \\
\text { Project }\end{array}$ \\
\hline & Hospitalizations & $\begin{array}{l}\text { The Number of } \\
\text { Hospital } \\
\text { Admissions } \\
\text { Related to } \\
\text { Uncontrolled } \\
\text { Diabetes }\end{array}$ & EHR & $0-10$ & Continuous & $\begin{array}{l}\text { Onset of } \\
\text { Intervention and } \\
\text { End of Project }\end{array}$ \\
\hline Outcome & Cost & $\begin{array}{l}\text { The Cost of } \\
\text { Treating } \\
\text { Patients for } \\
\text { Uncontrolled } \\
\text { Diabetes }\end{array}$ & $\begin{array}{l}\text { Hospital Bills } \\
\text { or Billing } \\
\text { Dept Records }\end{array}$ & $\begin{array}{l}>\$ 9,000 \text { per } \\
\text { year/person }\end{array}$ & Interval & $\begin{array}{l}\text { Onset of } \\
\text { Intervention and } \\
\text { End of Project }\end{array}$ \\
\hline & Cost Savings & $\begin{array}{l}\text { The Amount of } \\
\text { Money Saved } \\
\text { from Patients } \\
\text { Not Requiring } \\
\text { Treatment for } \\
\text { Uncontrolled } \\
\text { Diabetes }\end{array}$ & $\begin{array}{l}\text { Cost of } \\
\text { Services Prior } \\
\text { to Project } \\
\text { Minus the } \\
\text { Cost Analysis } \\
\text { After Project }\end{array}$ & $\begin{array}{l}>\$ 9,000 \text { per } \\
\text { year/person }\end{array}$ & Interval & $\begin{array}{l}\text { Onset of } \\
\text { Intervention and } \\
\text { End of Project }\end{array}$ \\
\hline & & & & & & \\
\hline
\end{tabular}


Figure 1: Results of the literature search using the PRISMA generator

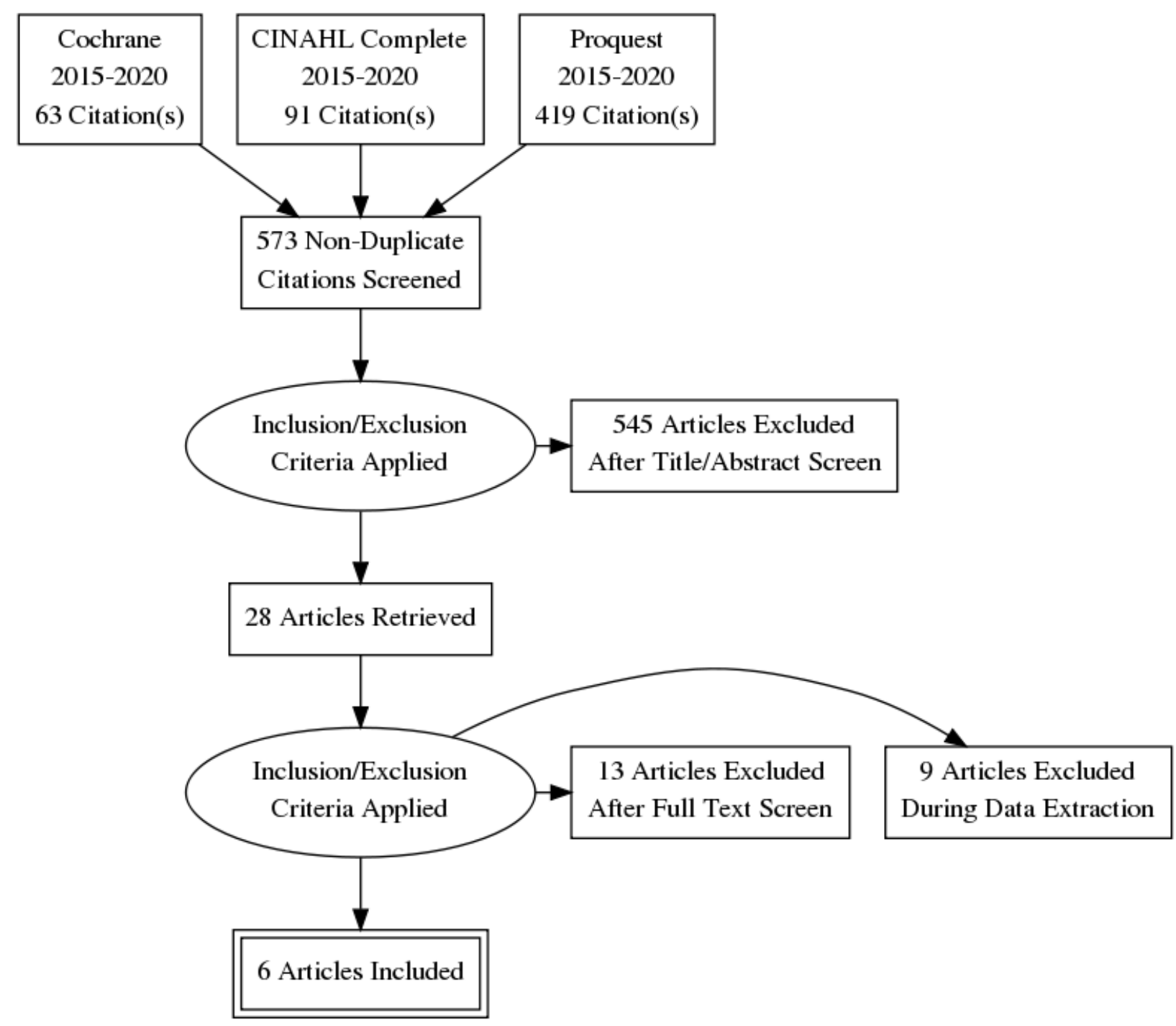


Figure 2: Level and grading of the evidence obtained using the Johns Hopkins EBP Model.

\begin{tabular}{|c|c|c|c|}
\hline CITATION & LEVEL & GRADE & QUALITY \\
\hline $\begin{array}{l}\text { Barker, K., Mallow, J., Theeke, L., \& Schwertfeger, } \\
\text { R. (2016). A telehealth rural practice change for } \\
\text { diabetes education and management. The Journal } \\
\text { for Nurse Practitioners, 12(16), pp. e225-e229. } \\
\text { Retrieved from } \\
\text { https://doi.org/10.1016/j.nurpra.2016.01.015 }\end{array}$ & Level 3 & Grade-A/B & $\begin{array}{l}\text { High/Good } \\
\text { Quality }\end{array}$ \\
\hline $\begin{array}{l}\text { Benson, G. A., Sidebottom, A., Hayes, J., Miedema, } \\
\text { M. D., Boucher, J., Vacquier, M....VanWormer, J. J. } \\
\text { (2019). Impact of ENHANCED (diEtitiaNs Helping } \\
\text { pAtieNts CarE for Diabetes) telemedicine } \\
\text { randomized controlled trial on diabetes optimal care } \\
\text { outcomes in patients with T2D. Journal of the } \\
\text { Academy of Nutrition and Dietetics, } 119(4), 585- \\
\text { 598. doi: } 10.1016 / \text { j.jand.2018.11.013 }\end{array}$ & Level 1 & Grade- A & High Quality \\
\hline $\begin{array}{l}\text { Mallow, J. A., Theeke, L. A., Barnes, E. R., } \\
\text { Whetsel, T., \& Mallow, B. K. (2015). Using } \\
\text { mHealth tools to improve rural diabetes care guided } \\
\text { by the chronic care model. Online Journal of Rural } \\
\text { Nursing Health Care, 14(1), 43-65. doi: } \\
\text { 10.14574/ojrnhc.v14i1.276 }\end{array}$ & Level IV & Grade-A & High Quality \\
\hline $\begin{array}{l}\text { Porter, J., Huggins, C. E., Truby, H., \& Collins, J. } \\
\text { (2016). The effect of using mobile technology-based } \\
\text { methods that record food or nutrient intake on } \\
\text { diabetes control and nutrition outcomes: A } \\
\text { systematic review. Nutrients, } 8(12), 815 . \text { doi: } \\
\text { http://dx.doi.org/10.3390/nu8120815 }\end{array}$ & Level 1 & Grade-B & Good Quality \\
\hline $\begin{array}{l}\text { Rush, K. L., Hatt, L., Janke, R., Burton, L., Ferrier, } \\
\text { M., \& Tetrault, M. (2018). The efficacy of } \\
\text { telehealth delivered educational approaches for } \\
\text { patients with chronic diseases: A systematic review. } \\
\text { Patient Education and Counseling,101(8):1310- } \\
\text { 1321. doi: } 10.1016 / \text { j.pec.2018.02.006 }\end{array}$ & Level 1 & Grade-A & High Quality \\
\hline $\begin{array}{l}\text { Russell, N. M., Vess, J., Durham, C., \& Johnson, E. } \\
\text { (2017). Text-Messaging to Support Diabetes Self- } \\
\text { Management in a Rural Health Clinic: A Quality } \\
\text { Improvement Project. Online Journal of Nursing } \\
\text { Informatics, 21(2), 9-1. Accession Number: } \\
\text { 128848064 }\end{array}$ & Level II & Grade-A/B & $\begin{array}{l}\text { High/Good } \\
\text { Quality }\end{array}$ \\
\hline
\end{tabular}


Figure 3: Ranked Values for Fasting Blood Sugar Pre and Post Intervention

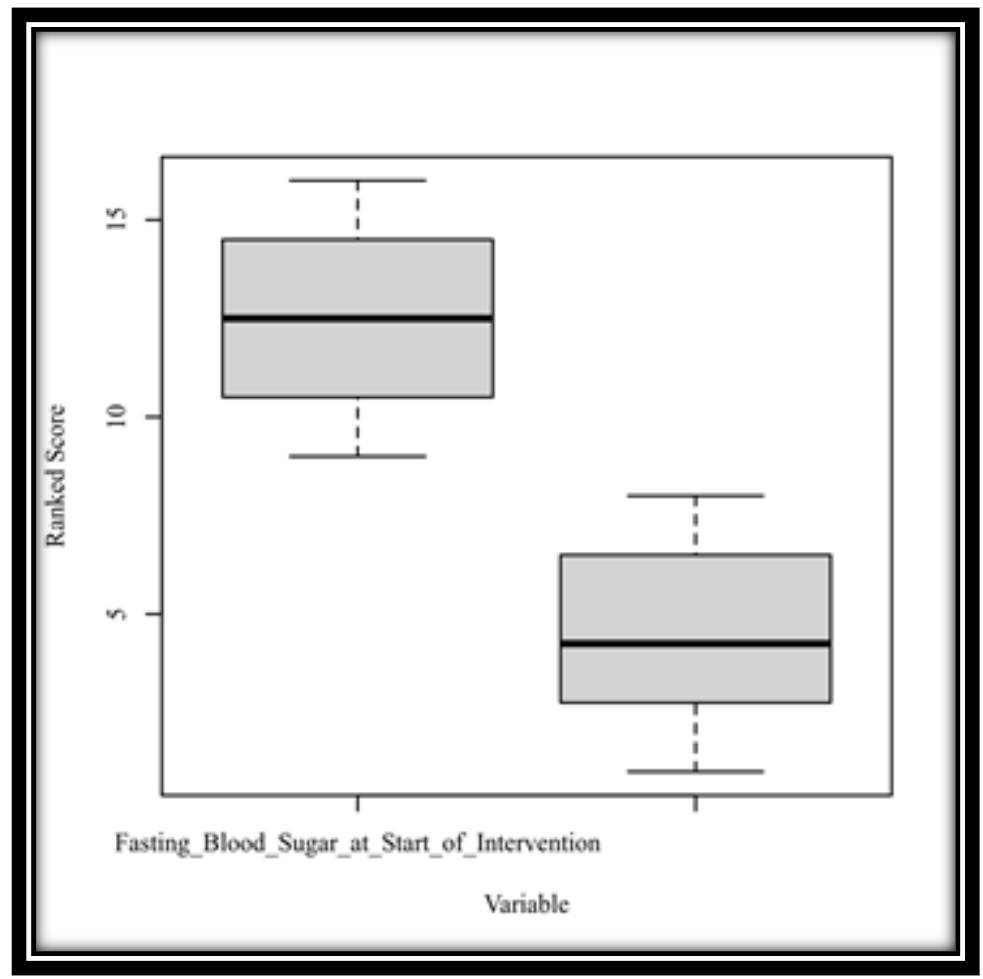


Figure 4: Summary Statistics Table for Interval and Ratio Variables

\begin{tabular}{lrrrrrrrr} 
Variable & $\boldsymbol{M}$ & $\boldsymbol{S D}$ & $\boldsymbol{n}$ & $\boldsymbol{S} \boldsymbol{E}_{\boldsymbol{M}}$ & Min & Max & Skewness & Kurtosis \\
\hline $\begin{array}{l}\text { Average fasting } \\
\text { blood sugar over } \\
8 \text {-weeks }\end{array}$ & 155.12 & 19.10 & 8 & 6.75 & 118.00 & 176.00 & -0.77 & -0.20 \\
\hline Weight lbs. & 173.62 & 52.29 & 8 & 18.49 & 86.00 & 236.00 & -0.64 & -0.87 \\
\hline Age & 48.50 & 16.38 & 8 & 5.79 & 23.00 & 73.00 & -0.07 & -1.02 \\
\hline $\begin{array}{l}\text { Fasting blood sugar } \\
\text { pre--intervention }\end{array}$ & 214.50 & 62.34 & 8 & 22.04 & 153.00 & 353.00 & 1.50 & 1.18 \\
\hline $\begin{array}{l}\text { Fasting blood sugar } \\
\text { post--intervention }\end{array}$ & 108.75 & 15.26 & 8 & 5.39 & 86.00 & 132.00 & -0.04 & -0.96 \\
\hline
\end{tabular}

Note. '-' indicates the statistic is undefined due to constant data or an insufficient sample size. 


\section{Appendix A}

Summary of Primary Research Evidence

\begin{tabular}{|c|c|c|c|c|c|c|}
\hline Citation & $\begin{array}{l}\text { Design, } \\
\text { Level } \\
\text { Quality } \\
\text { Grade }\end{array}$ & $\begin{array}{c}\text { Sample } \\
\text { Sample size }\end{array}$ & $\begin{array}{l}\text { Intervention } \\
\text { Comparison } \\
\text { (Definitions } \\
\text { should include } \\
\text { any specific } \\
\text { research tools } \\
\text { used along } \\
\text { with reliability } \\
\text { \& validity) }\end{array}$ & $\begin{array}{l}\text { Theoretical } \\
\text { Foundation }\end{array}$ & $\begin{array}{l}\text { Outcome } \\
\text { Definition }\end{array}$ & $\begin{array}{c}\text { Usefulness } \\
\text { Results } \\
\text { Key Findings }\end{array}$ \\
\hline $\begin{array}{l}\text { Barker, K., Mallow, J., Theeke, L., \& } \\
\text { Schwertfeger, R. (2016). A telehealth rural } \\
\text { practice change for diabetes education and } \\
\text { management. The Journal for Nurse } \\
\text { Practitioners, 12(16), pp. e225-e229. } \\
\text { Retrieved from } \\
\text { https://doi.org/10.1016/j.nurpra.2016.01.015 }\end{array}$ & $\begin{array}{l}\text { Prospective } \\
\text { Cohort } \\
\text { Design } \\
\text { Level } 3 \\
\text { High/Good } \\
\text { Quality } \\
\text { Grade A/B }\end{array}$ & $\begin{array}{l}\text { Ten participants } \\
\text { (patients with T2D) } \\
\text { were enrolled and } \\
8 \text { participants } \\
\text { completed the project. }\end{array}$ & $\begin{array}{l}\text { Telephone guided } \\
\text { (telehealth) } \\
\text { intervention by } \\
\text { NP-this guided } \\
\text { intervention was } \\
\text { based on } \\
\text { evidence-based } \\
\text { practice } \\
\text { guidelines by } \\
\text { ADA and AADE } \\
\text { (BSD) } \\
\text { Instrument-used } \\
\text { to assess health } \\
\text { behaviors }\end{array}$ & $\begin{array}{l}\text { AADE7 Self- } \\
\text { Care Behavior } \\
\text { Theoretical } \\
\text { Framework }\end{array}$ & $\begin{array}{l}\text { Improved } \\
\text { glycemic } \\
\text { control as } \\
\text { evidenced by } \\
\text { lower blood } \\
\text { glucose } \\
\text { levels }\end{array}$ & $\begin{array}{l}\text { Overall, this was an } \\
\text { effective project in } \\
\text { providing evidence to } \\
\text { support use of telephone } \\
\text { coaching/monitoring by NP } \\
\text { with encouraging behavior } \\
\text { modifications to improve } \\
\text { blood glucose levels. } \\
\text { Although statistical } \\
\text { significance was not } \\
\text { established due to limited } \\
\text { number of participants and } \\
\text { a short timeframe for } \\
\text { implementation and } \\
\text { evaluation, but there was } \\
\text { enough data to support } \\
\text { clinical significance. }\end{array}$ \\
\hline $\begin{array}{l}\text { Benson, G. A., Sidebottom, A., Hayes, J., } \\
\text { Miedema, M. D., Boucher, J., Vacquier, } \\
\text { M....VanWormer, J. J. (2019). Impact of } \\
\text { ENHANCED (diEtitiaNs Helping pAtieNts } \\
\text { CarE for Diabetes) telemedicine } \\
\text { randomized controlled trial on diabetes } \\
\text { optimal care outcomes in patients with T2D. } \\
\text { Journal of the Academy of Nutrition and } \\
\text { Dietetics, 119(4), 585-598. doi: } \\
\text { 10.1016/j.jand.2018.11.013 }\end{array}$ & $\begin{array}{l}\text { Randomized } \\
\text { Controlled } \\
\text { Trial } \\
\text { Level } 1 \\
\text { High } \\
\text { Quality } \\
\text { Grade A }\end{array}$ & $\begin{array}{l}\text { There was a total of } \\
118 \text { adult participants } \\
\text { with T2D; } 45 \% \text { of the } \\
\text { population were } \\
\text { females with a mean } \\
\text { age of } 60\end{array}$ & $\begin{array}{l}\text { Telemedicine } \\
\text { visits with a RDN } \\
\text { along with } \\
\text { treatment } \\
\text { protocols to } \\
\text { initiate and titrate } \\
\text { treatment } \\
\text { depending on the } \\
\text { glucose reading. } \\
\text { Telemedicine }\end{array}$ & $\begin{array}{l}\text { Collaborative } \\
\text { Team-Based } \\
\text { Models }\end{array}$ & $\begin{array}{l}\text { With } \\
\text { assistance } \\
\text { from the } \\
\text { interventions } \\
\text { provided, } \\
\text { patients were } \\
\text { able to } \\
\text { achieve their } \\
\text { care goals } \\
\text { with }\end{array}$ & $\begin{array}{l}\text { Use of telemedicine and an } \\
\text { RDN adhering to } \\
\text { medication treatment } \\
\text { protocol provides evidence } \\
\text { that can effectively improve } \\
\text { care for adults with T2D. }\end{array}$ \\
\hline
\end{tabular}




\begin{tabular}{|c|c|c|c|c|c|c|}
\hline & & & $\begin{array}{l}\text { visits versus } \\
\text { those that } \\
\text { received routine } \\
\text { care for diabetes } \\
\text { management }\end{array}$ & & $\begin{array}{l}\text { improved } \\
\text { behavior } \\
\text { modification. }\end{array}$ & \\
\hline $\begin{array}{l}\text { Mallow, J. A., Theeke, L. A., Barnes, E. R., } \\
\text { Whetsel, T., \& Mallow, B. K. } \\
\text { (2015). Using mHealth tools to improve } \\
\text { rural diabetes care guided by the chronic } \\
\text { care model. Online Journal of Rural } \\
\text { Nursing Health Care, 14(1), 43-65. doi: } \\
\text { 10.14574/ojrnhc.v14i1.276 }\end{array}$ & $\begin{array}{l}\text { Integrated } \\
\text { Review } \\
\text { Level IV } \\
\text { High } \\
\text { Quality } \\
\text { Grade A }\end{array}$ & $\begin{array}{l}\text { The review included } \\
23 \text { articles and } \\
\text { covered studies with } \\
\text { sample sizes from } 30 \\
\text { participants to } 123 \\
\text { participants who were } \\
\text { self-managing their } \\
\text { diabetes }\end{array}$ & $\begin{array}{l}\text { Use of mHealth } \\
\text { technologies to } \\
\text { include: text } \\
\text { messaging with } \\
\text { Bluetooth glucose } \\
\text { and exercise } \\
\text { monitoring; EHR, } \\
\text { mobile phone } \\
\text { apps were } \\
\text { utilized to upload } \\
\text { data to receive } \\
\text { real-time } \\
\text { feedback; } \\
\text { customized } \\
\text { schedules for } \\
\text { glucose } \\
\text { monitoring with } \\
\text { SMS reminders } \\
\text { (patients received } \\
\text { positive feedback } \\
\text { for results within } \\
\text { range and } \\
\text { instructions for } \\
\text { those out of } \\
\text { range. }\end{array}$ & $\begin{array}{l}\text { Chronic Care } \\
\text { Model }\end{array}$ & $\begin{array}{l}\text { Implementing } \\
\text { the chosen } \\
\text { interventions } \\
\text { yielded } \\
\text { improved } \\
\text { glycemic } \\
\text { control } \\
\text { (lower } \\
\text { glucose } \\
\text { levels; lower } \\
\text { average } \\
\text { blood glucose } \\
\text { readings), } \\
\text { lower blood } \\
\text { pressure } \\
\text { readings. }\end{array}$ & $\begin{array}{l}\text { This article supports } \\
\text { ongoing research as the } \\
\text { interventions unveiled } \\
\text { positive patient outcomes. } \\
\text { The interventions were } \\
\text { acceptable and effective. }\end{array}$ \\
\hline $\begin{array}{l}\text { Porter, J., Huggins, C. E., Truby, H., \& } \\
\text { Collins, J. (2016). The effect of using } \\
\text { mobile technology-based methods that } \\
\text { record food or nutrient intake on diabetes } \\
\text { control and nutrition outcomes: A } \\
\text { systematic review. Nutrients, } 8(12), 815 \text {. } \\
\text { doi: http://dx.doi.org/10.3390/nu8120815 }\end{array}$ & $\begin{array}{l}\text { Systematic } \\
\text { Review } \\
\text { Level 1 } \\
\text { Good } \\
\text { Quality } \\
\text { Grade B }\end{array}$ & $\begin{array}{l}\text { After reviewing the } \\
\text { literature from ( } 9 \\
\text { papers) random } \\
\text { control trials, the } \\
\text { samples sizes ranged } \\
\text { from } 20 \text { participants } \\
\text { (the smallest) to } 376 \\
\text { (the largest } \\
\text { population). }\end{array}$ & $\begin{array}{l}\text { Mobile electronic } \\
\text { devices (mobile } \\
\text { phones or tablets } \\
\text { or personal } \\
\text { digital assistants) } \\
\text { were used to } \\
\text { record nutritional } \\
\text { intake for the } \\
\text { population with } \\
\text { diabetes. } \\
\text { Those who } \\
\text { received the } \\
\text { intervention }\end{array}$ & $\begin{array}{l}\text { The PICO } \\
\text { framework was } \\
\text { used to } \\
\text { structure review } \\
\text { questions on the } \\
\text { participants } \\
\text { involved. }\end{array}$ & $\begin{array}{l}\text { Evidence } \\
\text { unveiled } \\
\text { improved } \\
\text { HbA1c levels } \\
\text { and lower } \\
\text { blood glucose } \\
\text { levels. }\end{array}$ & $\begin{array}{l}\text { Although there was a } \\
\text { significant improvement in } \\
\text { HbAlc(s), there is not clear } \\
\text { recommendations that } \\
\text { support the use of } \\
\text { technology to record dietary } \\
\text { data helps improve glucose } \\
\text { levels. }\end{array}$ \\
\hline
\end{tabular}




\begin{tabular}{|c|c|c|c|c|c|c|}
\hline & & & $\begin{array}{l}\text { while others } \\
\text { received routine } \\
\text { care. } \\
\text { Quality was } \\
\text { assessed using } \\
\text { the Quality } \\
\text { Criteria Checklist } \\
\text { for Primary } \\
\text { Research }\end{array}$ & & & \\
\hline $\begin{array}{l}\text { Rush, K. L., Hatt, L., Janke, R., Burton, L., } \\
\text { Ferrier, M., \& Tetrault, M. (2018). The } \\
\text { efficacy of telehealth delivered educational } \\
\text { approaches for patients with chronic } \\
\text { diseases: A systematic review. Patient } \\
\text { Education and Counseling,101(8):1310- } \\
\text { 1321. doi: } 10.1016 / \text { j.pec.2018.02.006 }\end{array}$ & $\begin{array}{l}\text { Systematic } \\
\text { Review } \\
\text { Level 1 } \\
\text { High } \\
\text { Quality } \\
\text { Grade A }\end{array}$ & $\begin{array}{l}16 \text { studies were } \\
\text { reviewed } \\
2,870 \text { Participants } \\
\text { from } 7 \text { countries } \\
\text { Patients with the } \\
\text { average age of } 54 \text { and } \\
\text { had one of the } \\
\text { following chronic } \\
\text { conditions: DM, IBD, } \\
\text { COPD, HF }\end{array}$ & $\begin{array}{l}\text { Telehealth } \\
\text { education } \\
\text { intervention } \\
\text { compared to } \\
\text { usual care } \\
\text { (routine physician } \\
\text { care and face-to- } \\
\text { face education) } \\
\text { Telehealth } \\
\text { Interventions } \\
\text { included web- } \\
\text { based, telephone, } \\
\text { videoconference, } \\
\text { and secure } \\
\text { television } \\
\text { DSMQ-16-item } \\
\text { instrument that } \\
\text { assesses } \\
\text { Self-management } \\
\text { activities in the } \\
\text { areas of glucose } \\
\text { management, } \\
\text { dietary control, } \\
\text { physical activity, } \\
\text { and healthcare } \\
\text { use } \\
\text { DKQ-Diabetes } \\
\text { Knowledge } \\
\text { Questionnaire }\end{array}$ & $\begin{array}{l}\text { Health Belief } \\
\text { Model and } \\
\text { Transtheoretical } \\
\text { Model }\end{array}$ & $\begin{array}{l}\text { Education via } \\
\text { virtual } \\
\text { modalities } \\
\text { proved more } \\
\text { effective than } \\
\text { the traditional } \\
\text { face-to-face } \\
\text { education. } \\
\text { Patients with } \\
\text { chronic } \\
\text { conditions } \\
\text { had improved } \\
\text { patient } \\
\text { outcomes as a } \\
\text { result of the } \\
\text { intervention. }\end{array}$ & $\begin{array}{l}\text { Education via virtual } \\
\text { modalities unveiled } \\
\text { evidence to support } \\
\text { implementation into clinical } \\
\text { practice. Findings from this } \\
\text { review have the potential to } \\
\text { direct future research aimed } \\
\text { at improving virtual } \\
\text { interventions }\end{array}$ \\
\hline
\end{tabular}




\begin{tabular}{|c|c|c|c|c|c|c|}
\hline $\begin{array}{l}\text { Russell, N. M., Vess, J., Durham, C., \& } \\
\text { Johnson, E. (2017). Text-Messaging to } \\
\text { Support Diabetes Self-Management in a } \\
\text { Rural Health Clinic: A Quality } \\
\text { Improvement Project. Online Journal of } \\
\text { Nursing Informatics, 21(2), 9-1. Accession } \\
\text { Number: } 128848064\end{array}$ & $\begin{array}{l}\text { Quasi- } \\
\text { experimental } \\
\text { study } \\
\text { Level II } \\
\text { High/Good } \\
\text { Quality } \\
\text { Grade A/B }\end{array}$ & $\begin{array}{l}\text { The QI project } \\
\text { participants included } \\
\text { all patients } \\
\text { with diabetes managed } \\
\text { at the free clinic in } \\
\text { Southeastern U.S. that } \\
\text { chose to participate in } \\
\text { the text message } \\
\text { program. } \\
\text { The mean age of } \\
\text { participants was } 50 \\
\text { years old. Of the } 49 \\
\text { participants, } 65 \% \\
\text { were African } \\
\text { American, } 33 \% \\
\text { Caucasian, and } 2 \% \\
\text { Hispanic. Twenty-four } \\
\text { of the participants } \\
\text { were female; } 67 \% \text { of } \\
\text { female participants } \\
\text { were African } \\
\text { American, } 29 \% \text { were } \\
\text { Caucasian, and } 4 \% \\
\text { were Hispanic. } \\
\text { Twenty-five } \\
\text { participants were } \\
\text { male, with } 64 \% \text { being } \\
\text { African American and } \\
9 \% \text { Caucasian. }\end{array}$ & $\begin{array}{l}\text { Text messaging } \\
\text { interventions to } \\
\text { support diabetes } \\
\text { self-management } \\
\text { with behavior } \\
\text { modification } \\
\text { (medication } \\
\text { compliance, } \\
\text { glucose } \\
\text { monitoring, diet, } \\
\text { and exercise). } \\
\text { Text messages } \\
\text { were sent through } \\
\text { a secure, } \\
\text { messaging system } \\
\text { called } \\
\text { CareMessage. }\end{array}$ & $\begin{array}{l}\text { Chronic Care } \\
\text { Model } \\
\text { Framework }\end{array}$ & $\begin{array}{l}\text { There was a } \\
11.3 \% \\
\text { reduction of } \\
\text { fasting blood } \\
\text { glucose } \\
\text { levels (blood } \\
\text { sugar reading } \\
\text { prior to } \\
\text { eating, but } \\
\text { after going at } \\
\text { least } 8 \text { hours } \\
\text { without } \\
\text { food). }\end{array}$ & $\begin{array}{l}\text { The intervention was } \\
\text { effective in achieving the } \\
\text { desired outcome. Although } \\
\text { the project was a success, } \\
\text { there were limitations that } \\
\text { presented; some of these } \\
\text { included patient's failing to } \\
\text { respond, technical issues, } \\
\text { and data entry errors. } \\
\text { Another limitation was time } \\
\text { constraints, length of the } \\
\text { study, to obtain an HbAlc } \\
\text { level which is one of the } \\
\text { key factors to effectively } \\
\text { monitor control and } \\
\text { diabetes management. } \\
\text { Integrating an evidence- } \\
\text { based text messaging } \\
\text { system along with other } \\
\text { interventions will be } \\
\text { beneficial in diabetes } \\
\text { management. }\end{array}$ \\
\hline
\end{tabular}

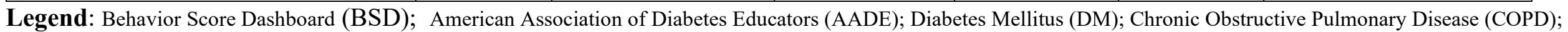

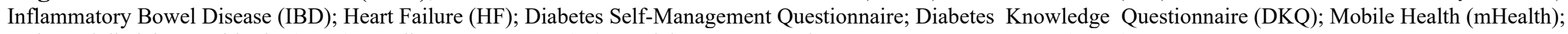
registered dietician nutritionist (RDN); Quality Improvement (QI); Participant-Intervention-Comparator-Outcomes (PICO) 
Appendix B

Summary of Systematic Reviews (SR)

\begin{tabular}{|c|c|c|c|c|c|c|c|}
\hline Citation & $\begin{array}{l}\text { Quality } \\
\text { Grade }\end{array}$ & Question & Search Strategy & $\begin{array}{l}\text { Inclusion/ } \\
\text { Exclusion Criteria }\end{array}$ & $\begin{array}{l}\text { Data Extraction and } \\
\text { Analysis }\end{array}$ & Key Findings & $\begin{array}{l}\text { Usefulness/Recom } \\
\text { mendation/ } \\
\text { Implications }\end{array}$ \\
\hline \begin{tabular}{|l|} 
Porter, J., \\
Huggins, \\
C. E., \\
Truby, H., \\
\& Collins, \\
J. (2016). \\
The effect \\
of using \\
mobile \\
technolog \\
y-based \\
methods \\
that \\
record \\
food or \\
nutrient \\
intake on \\
diabetes \\
control \\
and \\
nutrition \\
outcomes: \\
A \\
systematic \\
review. $N$ \\
utrients, 8 \\
(12), 815. \\
doi: \\
http://dx.d \\
oi.org/10. \\
$3390 /$ nu8 \\
120815
\end{tabular} & $\begin{array}{l}\text { Level 1 } \\
\text { Good } \\
\text { Quality } \\
\text { Grade B }\end{array}$ & $\begin{array}{l}\text { Does the effectiveness of } \\
\text { using mobile electronic } \\
\text { devices to record food or } \\
\text { nutrient intake on diabetes } \\
\text { control and nutrition } \\
\text { outcomes? }\end{array}$ & \begin{tabular}{|l|} 
Systematic Reviews, \\
PsycINFO and EBM \\
Reviews-Health \\
Technology \\
Assessment, were \\
searched to identify \\
publications of \\
relevance from date \\
of commencement to \\
September 2016. \\
Reference lists of \\
papers included in the \\
final library were also \\
reviewed to identify \\
additional studies for \\
inclusion. The \\
process of \\
identification, \\
screening and \\
eligibility assessment \\
was applied to ensure \\
that all relevant \\
studies were \\
included.
\end{tabular} & $\begin{array}{l}\text { Studies with no intervention } \\
\text { (e.g., cross-sectional } \\
\text { studies) or no control group } \\
\text { (e.g., before-and-after } \\
\text { studies), reviews, opinions } \\
\text { or commentaries, protocol } \\
\text { papers, conference abstracts, } \\
\text { book chapters and case } \\
\text { reports were excluded from } \\
\text { the review. } \\
\\
\text { The PICO (Participant- } \\
\text { Intervention-Comparator- } \\
\text { Outcomes design) format of } \\
\text { Shamseer et al. [13] was } \\
\text { used to develop criteria for } \\
\text { review inclusion. Original } \\
\text { research among people with } \\
\text { type } 1 \text { or } 2 \text { diabetes mellitus } \\
\text { or gestational diabetes } \\
\text { (excluding pre-diabetes or } \\
\text { diabetes prevention) with } \\
\text { any treatment regimen, } \\
\text { using mobile electronic } \\
\text { devices where food or } \\
\text { nutrient intake was recorded } \\
\text { (alone or in addition to other } \\
\text { parameters) and compared } \\
\text { with usual care or } \\
\text { alternative treatment models } \\
\text { was considered. }\end{array}$ & \begin{tabular}{|l|} 
A template was \\
developed to extract \\
relevant data from the \\
original papers with \\
data extraction \\
completed by one \\
author (J.C.). Two \\
authors \\
independently rated \\
study quality using \\
the Quality Criteria \\
Checklist for Primary \\
Research (J.P., \\
C.E.H.) [14]. This \\
tool considers aspects \\
of dietary \\
measurement and \\
error and is specific \\
for studies in \\
nutrition and \\
dietetics.
\end{tabular} & \begin{tabular}{l|} 
There was a statistically \\
significantly greater \\
improvement in HbA1c \\
in the intervention group \\
compared to the control \\
group in four of nine \\
studies. Due to the \\
multiple and varied \\
components of the \\
intervention and usual \\
care, it was not possible \\
to attribute whether the \\
effect (or lack of) on \\
HbAlc was attributable \\
to recording of food or \\
nutrient intake using a \\
mobile device.
\end{tabular} & \begin{tabular}{|l} 
Although \\
technology may \\
offer novel \\
solutions to support \\
measurement of \\
dietary intake and \\
improve clinical \\
outcomes in people \\
with diabetes, based \\
on the present \\
evidence, we are \\
unable to define \\
clear \\
recommendations \\
for nutrition \\
technology use in \\
this population.
\end{tabular} \\
\hline
\end{tabular}




\begin{tabular}{|c|c|c|c|c|c|c|c|}
\hline Citation & $\begin{array}{l}\text { Quality } \\
\text { Grade }\end{array}$ & Question & Search Strategy & $\begin{array}{l}\text { Inclusion/ } \\
\text { Exclusion Criteria }\end{array}$ & $\begin{array}{l}\text { Data Extraction and } \\
\text { Analysis }\end{array}$ & Key Findings & $\begin{array}{l}\text { Usefulness/Recom } \\
\text { mendation/ } \\
\text { Implications }\end{array}$ \\
\hline $\begin{array}{l}\text { Rush, K. } \\
\text { L., Hatt, } \\
\text { L., Janke, } \\
\text { R., } \\
\text { Burton, } \\
\text { L., } \\
\text { Ferrier, } \\
\text { M., \& } \\
\text { Tetrault, } \\
\text { M. } \\
\text { (2018). } \\
\text { The } \\
\text { efficacy } \\
\text { of } \\
\text { telehealth } \\
\text { delivered } \\
\text { education } \\
\text { al } \\
\text { approache } \\
\text { s for } \\
\text { patients } \\
\text { with } \\
\text { chronic } \\
\text { diseases: } \\
\text { A } \\
\text { systematic } \\
\text { review. } \\
\text { Patient } \\
\text { Education } \\
\text { and } \\
\text { Counselin } \\
\text { g,101(8):1 } \\
310-1321 . \\
\text { doi: } \\
10.1016 / \text { j. } \\
\text { pec.2018. } \\
02.006\end{array}$ & $\begin{array}{l}\text { Level 1 } \\
\text { High } \\
\text { Quality } \\
\text { Grade A }\end{array}$ & $\begin{array}{l}\text { Does the efficacy of } \\
\text { telehealth delivery of } \\
\text { educational approaches } \\
\text { improve patient outcomes } \\
\text { when compared to usual } \\
\text { care? }\end{array}$ & $\begin{array}{l}\text { Systematic review } \\
\text { using MEDLINE, } \\
\text { CINAHL, and } \\
\text { EMBASE databases } \\
\text { using the search } \\
\text { words telehealth, } \\
\text { chronic disease, } \\
\text { patient education, and } \\
\text { related concepts. } \\
\text { This yielded } 2447 \\
\text { articles published } \\
\text { from } 2006 \text { to } 2017 . \\
\text { Only papers that } \\
\text { compared virtual } \\
\text { education with usual } \\
\text { care were chosen. }\end{array}$ & $\begin{array}{l}\text { Modalities included the use } \\
\text { of web, telephone, } \\
\text { videoconference, and/or } \\
\text { television. } \\
\text { Studies that compared } \\
\text { telehealth education with } \\
\text { usual care, education as the } \\
\text { key intervention, and } \\
\text { English copies published } \\
\text { between } 2006-2017 \text { were } \\
\text { included. Also, the studies } \\
\text { had to have knowledge and } \\
\text { information giving as the } \\
\text { primary activities. } \\
\text { Exclusion criteria included } \\
\text { the following: if education } \\
\text { was not the primary focus of } \\
\text { the study; if the subjects } \\
\text { were children and/or youths; } \\
\text { if education activities were } \\
\text { only described, but not } \\
\text { tested; qualitative studies; if } \\
\text { the study only reported only } \\
\text { research protocol. }\end{array}$ & $\begin{array}{l}\text { Two trained Research } \\
\text { Assistants extracted } \\
\text { data from the selected } \\
\text { papers. The data } \\
\text { included: author/year } \\
\text { of publication, } \\
\text { country in which the } \\
\text { study was conducted, } \\
\text { study design (quasi- } \\
\text { experimental, } \\
\text { experimental, } \\
\text { observation, } \\
\text { randomized control } \\
\text { trial), sample size } \\
\text { (total, and sub- } \\
\text { groups, if relevant), } \\
\text { number and types of } \\
\text { study groups, } \\
\text { relevant sample } \\
\text { demographics (age, } \\
\text { urban/rural, chronic } \\
\text { disease), and drop- } \\
\text { out rate. Additional } \\
\text { data extraction } \\
\text { included: virtual } \\
\text { education modality, } \\
\text { educational } \\
\text { intervention } \\
\text { description, duration, } \\
\text { and frequency of } \\
\text { intervention, } \\
\text { comparator, outcome } \\
\text { measures, and results. } \\
\text { A quality rating was } \\
\text { derived for each } \\
\text { paper using the } \\
\text { quality assessment }\end{array}$ & $\begin{array}{l}\text { Virtual education } \\
\text { delivered to patients } \\
\text { with chronic diseases } \\
\text { was comparable, or } \\
\text { more effective, than } \\
\text { usual care. }\end{array}$ & \begin{tabular}{|l} 
Virtual education \\
was as, or more \\
effective than usual \\
care and had a \\
significant impact \\
on patient \\
outcomes, with \\
important \\
implications for \\
educators. \\
Findings from this \\
review have the \\
potential to direct \\
future research \\
aimed at improving \\
virtual \\
interventions. \\
Future research \\
should employ \\
consistently \\
rigorous designs \\
including larger, \\
randomized samples \\
to reduce self- \\
selection bias.
\end{tabular} \\
\hline
\end{tabular}




\begin{tabular}{|c|c|c|c|c|c|c|c|}
\hline Citation & Quality & Question & Search Strategy & $\begin{array}{l}\text { Inclusion/ } \\
\text { Exclusion Criteria }\end{array}$ & $\begin{array}{l}\text { Data Extraction and } \\
\text { Analysis }\end{array}$ & Key Findings & $\begin{array}{l}\text { Usefulness/Recom } \\
\text { mendation/ } \\
\text { Implications }\end{array}$ \\
\hline & & & & & $\begin{array}{l}\text { tool for quantitative } \\
\text { studies developed by } \\
\text { the National } \\
\text { Collaborating Centre } \\
\text { for Methods and } \\
\text { Tools. Studies were } \\
\text { rated as strong, } \\
\text { moderate, or weak } \\
\text { according to six } \\
\text { components: } \\
\text { selection bias, study } \\
\text { design, confounders, } \\
\text { blinding, data } \\
\text { collection method, } \\
\text { and withdrawals and } \\
\text { dropouts. Component } \\
\text { ratings were used to } \\
\text { derive a global rating, } \\
\text { of } 1 \text { (no weak } \\
\text { ratings), } 2 \text { (one weak } \\
\text { rating) or } 3 \text { (two or } \\
\text { more weak ratings) } \\
\text { with lower scores of } \\
\text { higher } \\
\text { methodological } \\
\text { quality. Two } \\
\text { independent } \\
\text { reviewers did all } \\
\text { ratings, discussing } \\
\text { any discrepancies } \\
\text { until a consensus was } \\
\text { reached. Any papers } \\
\text { with a global rating } \\
\text { of weak were } \\
\text { excluded from the } \\
\text { review. }\end{array}$ & & \\
\hline
\end{tabular}


Appendix C

\section{Project Schedule}

\begin{tabular}{|c|c|c|c|c|c|c|c|c|c|c|c|c|c|c|c|c|c|c|c|c|c|c|c|c|}
\hline & \multicolumn{8}{|c|}{ NUR7801 } & \multicolumn{8}{|c|}{ NUR7802 } & \multicolumn{8}{|c|}{ NUR7803 } \\
\hline 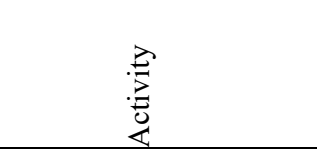 & $\begin{array}{l}7 \\
\frac{y}{0} \\
3\end{array}$ & $\begin{array}{l}n \\
\frac{n}{2} \\
3 \\
3\end{array}$ & $\begin{array}{l}n \\
\frac{4}{0} \\
3 \\
3\end{array}$ & $\frac{\pi}{8}$ & $\frac{a}{4}$ & $\begin{array}{l}= \\
\frac{y}{8} \\
\frac{0}{3}\end{array}$ & $\begin{array}{l}\frac{m}{3} \\
\frac{\pi}{0} \\
3\end{array}$ & $\frac{n}{3}$ & $\frac{\bar{y}}{\overline{0}}$ & $\begin{array}{l}\frac{n}{2} \\
\frac{d}{3}\end{array}$ & $\begin{array}{l}n \\
\frac{1}{0} \\
\frac{1}{3}\end{array}$ & $\frac{5}{3}$ & $\begin{array}{l}\hat{y} \\
\bar{d} \\
\dot{3}\end{array}$ & $\begin{array}{l}= \\
\frac{y}{8} \\
3\end{array}$ & $\begin{array}{l}\frac{m}{w} \\
\frac{\pi}{0} \\
3\end{array}$ & $\frac{n}{\frac{n}{0}}$ & $\begin{array}{l}\bar{y} \\
\frac{y}{0} \\
3\end{array}$ & $\begin{array}{l}m \\
\frac{2}{0} \\
0 \\
3\end{array}$ & $\begin{array}{l}n \\
\frac{n}{0} \\
0 \\
3\end{array}$ & $\frac{y}{8}$ & $\begin{array}{l}\frac{a}{0} \\
\frac{0}{3} \\
3\end{array}$ & $\begin{array}{l}= \\
\frac{\vec{v}}{0} \\
\sum_{3}^{0}\end{array}$ & $\begin{array}{l}\frac{m}{2} \\
\frac{\pi}{0} \\
\frac{0}{3}\end{array}$ & $\begin{array}{l}\frac{n}{y} \\
\frac{y}{8} \\
3\end{array}$ \\
\hline Meet with Preceptor & & & & & & & & & & & & & & & & & & & & & & & & \\
\hline Meet with Mentor & & & & & & & & & & & & & & & & & & & & & & & & \\
\hline $\begin{array}{l}\text { Prepare Project } \\
\text { Proposal for } \\
\text { Submission }\end{array}$ & & & & & & & & & & & & & & & & & & & & & & & & \\
\hline PLANNING & & & & & & & & & & & & & & & & & & & & & & & & \\
\hline PICOT Approval & & & & & & & & & & & & & & & & & & & & & & & & \\
\hline $\begin{array}{l}\text { Review of Literature } \\
\text { Refine Topic }\end{array}$ & & & & & & & & & & & & & & & & & & & & & & & & \\
\hline $\begin{array}{l}\text { Identify Themes and } \\
\text { Concepts }\end{array}$ & & & & & & & & & & & & & & & & & & & & & & & & \\
\hline Consult Writing Center & & & & & & & & & & & & & & & & & & & & & & & & \\
\hline $\begin{array}{l}\text { Organize Meeting(s) to } \\
\text { Identify Stakeholders, } \\
\text { Present Project Scope, } \\
\text { Establish Budget, } \\
\text { Assign Tasks } \\
\text { According to Area of } \\
\text { Expertise, Set Goals, } \\
\text { Identify Expected } \\
\text { Outcomes }\end{array}$ & & & & & & & & & & & & & & & & & & & & & & & & \\
\hline $\begin{array}{l}\text { Organization/ } \\
\text { Leadership Assessment }\end{array}$ & & & & & & & & & & & & & & & & & & & & & & & & \\
\hline $\begin{array}{l}\text { Apply/Obtain USA } \\
\text { EPRC Approval }\end{array}$ & & & & & & & & & & & & & & & & & & & & & & & & \\
\hline $\begin{array}{l}\text { Apply/Obtain UAB } \\
\text { (facility) Approval }\end{array}$ & & & & & & & & & & & & & & & & & & & & & & & & \\
\hline
\end{tabular}




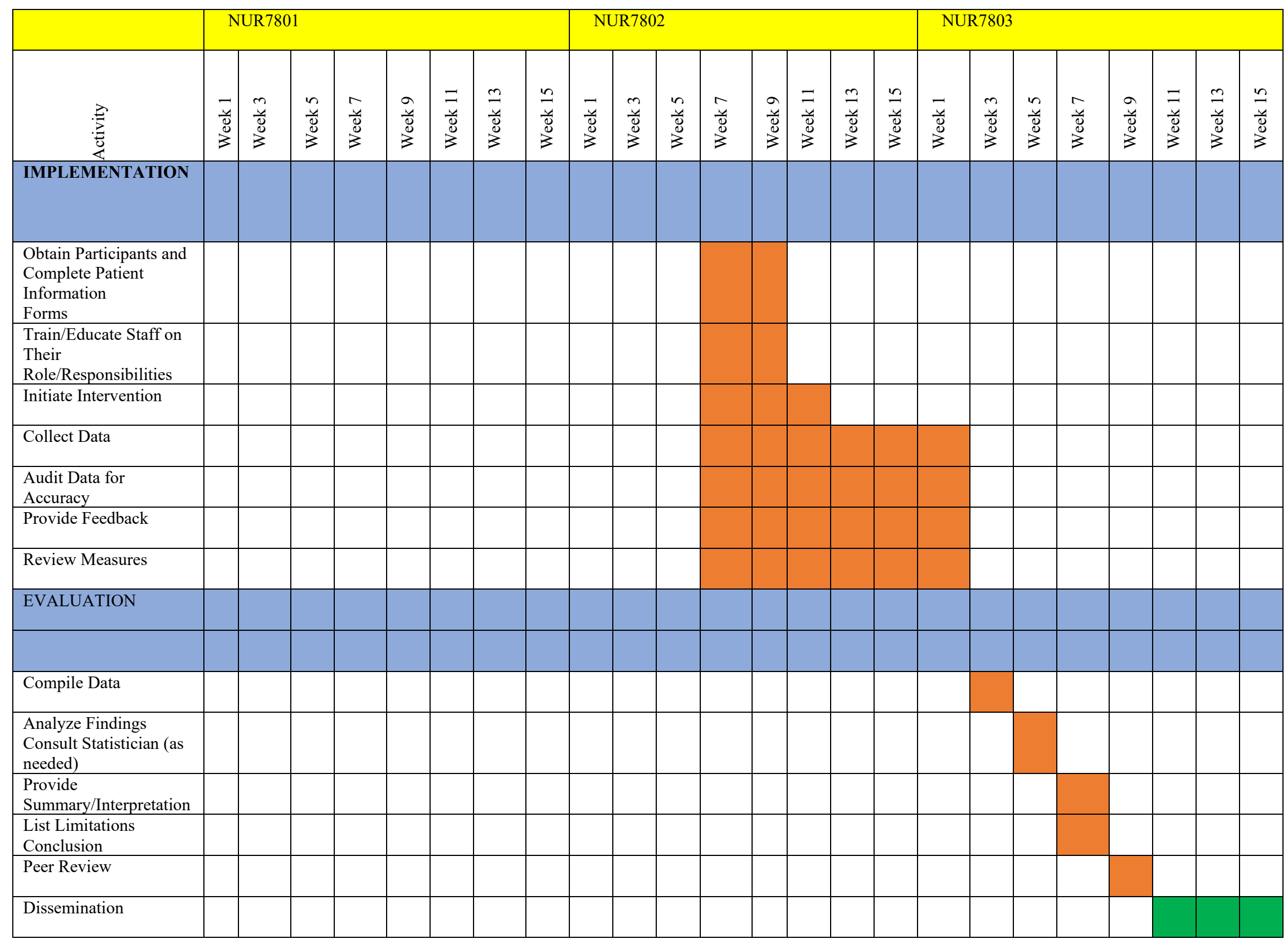




\section{Appendix D}

\section{Data Collection Tool for Evaluation}

\begin{tabular}{|c|c|c|c|c|c|c|c|}
\hline $\begin{array}{l}\text { Participant } \\
\text { Information } \\
\text { ID }\end{array}$ & $\begin{array}{l}\text { A } \\
G \\
\text { E }\end{array}$ & $\begin{array}{l}\text { G } \\
\text { E } \\
N \\
D \\
\text { E } \\
\text { R }\end{array}$ & $\begin{array}{l}\mathrm{R} \\
\mathrm{A} \\
\mathrm{C} \\
\mathrm{E}\end{array}$ & WEIGHT & $\begin{array}{l}\text { FASTING BLOOD } \\
\text { SUGAR }\end{array}$ & $\begin{array}{l}\text { NUMBER OF } \\
\text { HYPERGLYCEMIC } \\
\text { EPISODES }\end{array}$ & $\begin{array}{l}\text { NUMBER OF } \\
\text { HOSPITALIZATIONS } \\
\text { RELATED TO } \\
\text { UNCONTROLLED } \\
\text { DIABETES }\end{array}$ \\
\hline & & & & & & & \\
\hline & & & & & & & \\
\hline & & & & & & & \\
\hline & & & & & & & \\
\hline & & & & & & & \\
\hline & & & & & & & \\
\hline & & & & & & & \\
\hline & & & & & & & \\
\hline & & & & & & & \\
\hline & & & & & & & \\
\hline & & & & & & & \\
\hline & & & & & & & \\
\hline
\end{tabular}

ADCES, 2020; AHIMA, 2018 
Appendix E

\section{SWOT ANALYSIS}
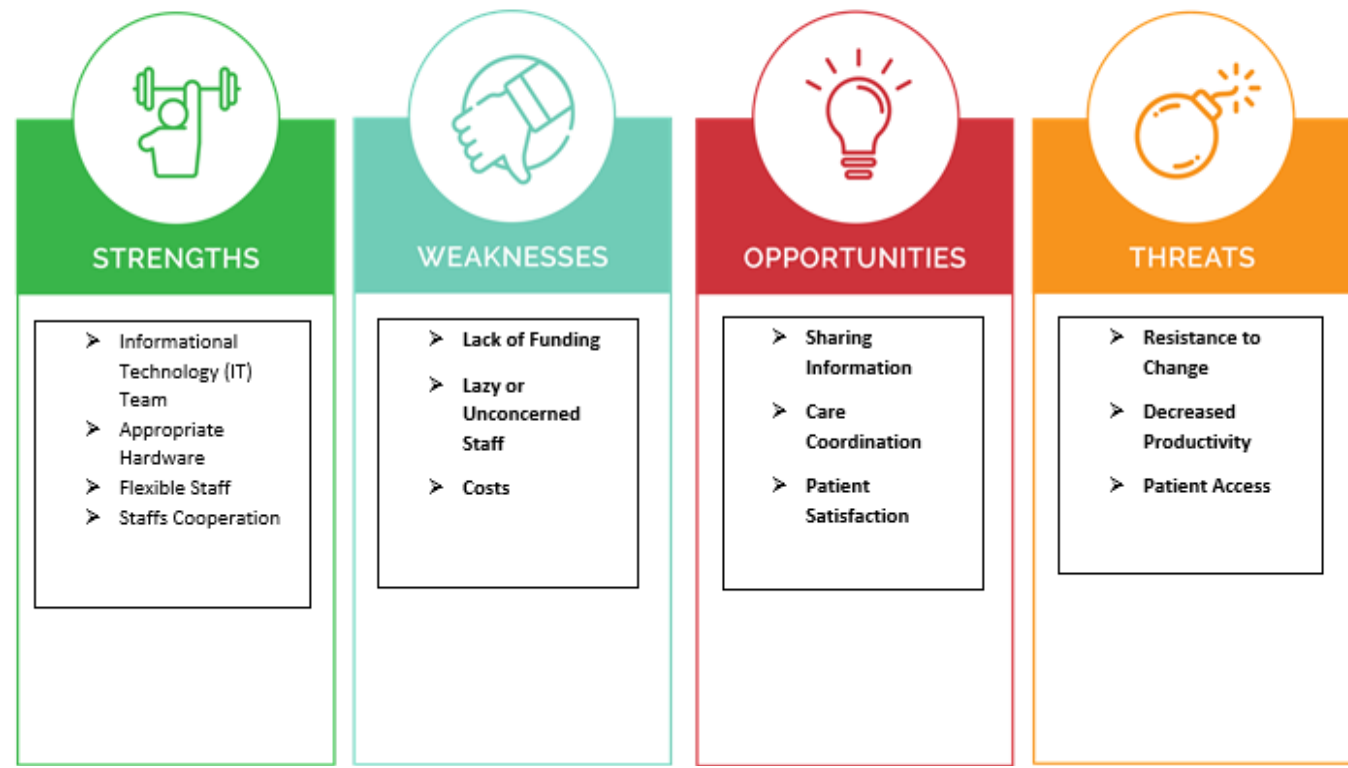

TemplateLab, n.d
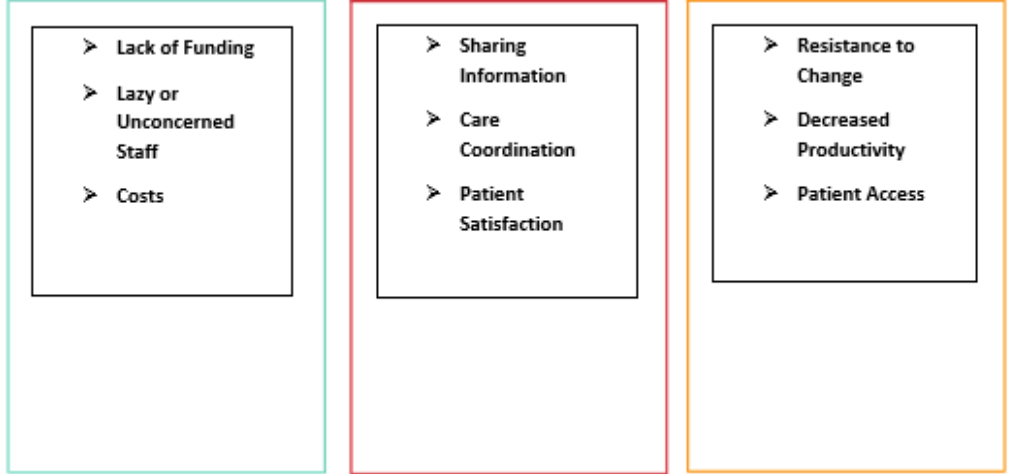


\section{Appendix F}

Project Timeline

\begin{tabular}{|l|l|l|}
\hline \multicolumn{1}{|c|}{ Task } & \multicolumn{1}{|c|}{ Time Frame } & Responsible Person(s) \\
\hline $\begin{array}{l}\text { 1. IRB Approval from the } \\
\text { University \& Facility }\end{array}$ & $2 / 10 / 21-03 / 04 / 21$ & DNP Student \\
\hline $\begin{array}{l}\text { 2. Meet with key stakeholders } \\
\text { 3. Identify Participants }\end{array}$ & $3 / 09 / 21$ & $\begin{array}{l}\text { DNP Student, Preceptor, } \\
\text { GTF, EC }\end{array}$ \\
\hline $\begin{array}{l}\text { 4. Organize and Conduct Staff \& } \\
\text { Patient Training }\end{array}$ & $3 / 15 / 21-4 / 19 / 21$ & DNP Student, CM \\
\hline $\begin{array}{l}\text { 5. Begin Technology Intervention } \\
\text { to Gain Glycemic Control in } \\
\text { Patients with Diabetes }\end{array}$ & $3 / 22 / 21-5 / 27 / 21$ & $\begin{array}{l}\text { DNP Student and } \\
\text { Education Coordinator }\end{array}$ \\
\hline 6. Collect and Analyze Data & $6 / 03 / 21-6 / 18 / 21$ & $\begin{array}{l}\text { DNP Student and } \\
\text { Healthcare Champions }\end{array}$ \\
\hline 7. Report Project Findings (Results) & $06 / 22 / 21$ & $\begin{array}{l}\text { DNP Student and } \\
\text { Preceptor }\end{array}$ \\
\hline $\begin{array}{l}\text { 8. Collaborate with the Writing } \\
\text { Center about Project Dissemination }\end{array}$ & $6 / 23 / 21-6 / 25 / 21$ & DNP Student \\
\hline 9. Disseminate Results & $6 / 29 / 21-7 / 02 / 21$ & DNP Student \\
\hline
\end{tabular}




\section{Appendix G}

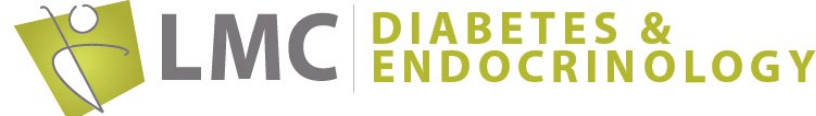

\section{LMC Diabetes Skills, Confidence \& Preparedness Index (SCPI)}

Answer the following questions on a scale of $1-10(1=$ very little and $10=$ a lot $)$. Please do this by drawing a line on the scale where you see yourself for each question.

1. I am able to portion out and choose foods that have the optimal balance between carbohydrates, proteins and vegetables to help keep my blood sugars in target.
1 (very little)
10 (a lot)

2. I know how my diabetes insulin or medication works in my body and at which time of day I should check my blood sugars to make sure my dose is correct.

1 (very little) 10 (a lot)

3. I feel confident that I can plan balanced meals and snacks effectively.

$$
1 \text { (very little) } \quad 10 \text { (a lot) }
$$

4. If I miss a dose of my insulin or medication, I know how my body will react and the steps to take to get back on track.

$$
1 \text { (very little) } 10 \text { (a lot) }
$$

5. When I am planning to exercise, I know what changes I need to make to avoid a low blood sugar before, during, and after exercise.

$$
1 \text { (very little) } \quad 10 \text { (a lot) }
$$

6. I am confident that I can implement stress management techniques into my lifestyle.

1 (very little) $\quad 10$ (a lot)

7. I know when to check my blood sugar if I want to see how my body reacted to a meal.

$$
1 \text { (very little) } \quad 10 \text { (a lot) }
$$

8. When I am sick, I know what to do differently with my medications, fluid intake, food intake, blood sugar testing, and when to go to the hospital. 


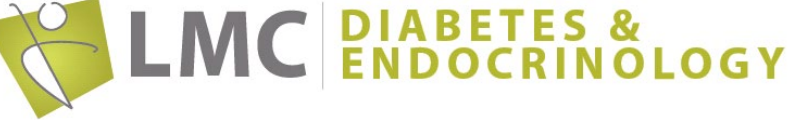

1 (very little)

10 (a lot)

9. I intend to start planning and eating balanced meals and snacks starting next week.
1 (very little)
10 (a lot)

10. I know how to identify stress in my life and how it can impact my diabetes management \& overall health.

$$
1 \text { (very little) } 10 \text { (a lot) }
$$

11. I'm confident that I can plan ahead for what to do, and how to react, either before, during or after exercise to avoid a low blood sugar.

$$
1 \text { (very little) } \quad 10 \text { (a lot) }
$$

12. When I look at my blood sugars in my meter or in my logbook in a given week, I could explain to my diabetes educator or doctor what my blood sugar pattern is.

$$
1 \text { (very little) } \quad 10 \text { (a lot) }
$$

13. I plan to choose an activity and begin incorporating it into my schedule in the coming week.

$$
1 \text { (very little) } \quad 10 \text { (a lot) }
$$

14. I am confident that at the next time I am eating out of my home, I will be able to plan and select the foods that best keep my blood sugars under control.

$$
1 \text { (very little) } \quad 10 \text { (a lot) }
$$

15. I plan to start using my blood sugar levels to make changes to my diet and/or insulin starting next week.

$$
1 \text { (very little) } \quad 10 \text { (a lot) }
$$

16. I am confident that I can choose a healthy activity for me and include it into my schedule.

$$
1 \text { (very little) } \quad 10 \text { (a lot) }
$$

17. I plan to start making a list of stress management techniques which will work for me in the upcoming week. 


$$
1 \text { (very little) } \quad 10 \text { (a lot) }
$$

18. I am confident that I can adjust my insulin or medication doses, on my own, to reach the target blood sugar levels.

$$
1 \text { (very little) } \quad 10 \text { (a lot) }
$$

19. I am confident that I can commit to preventing and monitoring my diabetes complications such as seeing my eye doctor at least once a year and checking my feet on a daily basis.

$$
1 \text { (very little) } \quad 10 \text { (a lot) }
$$

20. I plan to start adjusting my insulin or medication doses on my own starting next week.

$$
1 \text { (very little) } 10 \text { (a lot) }
$$

21. I am confident that I will use my blood sugar results to make changes to my diet and/or insulin to help keep my blood sugars in target.

$$
1 \text { (very little) } \quad 10 \text { (a lot) }
$$

22. I know what the ABCs (A1c, Blood Pressure, and Cholesterol) of Diabetes are, what my targets are and how they impact my diabetes.

$$
1 \text { (very little) } 10 \text { (a lot) }
$$

23. I plan to start looking for patterns in my meter or logbook starting next week.

$$
1 \text { (very little) } 10 \text { (a lot) }
$$

24. The next time I am sick, I will make the necessary changes to my medications, insulin and/or eating depending on my blood sugars.

$$
1 \text { (very little) } 10 \text { (a lot) }
$$

25. With my next exercise, I am going to make a plan to reduce the chance of a low blood sugar, or to react with a good response if I do have a low blood sugar.

$$
1 \text { (very little) } \quad 10 \text { (a lot) }
$$

Mbuagbaw et al., 2017 


\section{Appendix $\mathbf{H}$}

Coaching Interventions

Behavior Modifications

$>$ Positive Reinforcement-encourage increased physical activity, dietary provisions, and improved eating habits

Dietary Recommendations (unless otherwise contraindicated)

$>$ Avoid foods high is starch, sodas, fruit juices

$>$ Meal Planning

$>$ Carb Counting

$>$ Portion Size (CDC.gov, 2020)

Physical Activity (unless otherwise contraindicated)

$>$ Engage in some type of physical activity at least 30 minutes daily

$>$ Utilize a pedometer to count your steps

$>$ Park away for door entrances

$>$ Walk in the mall or grocery stores (ADCES, 2020; AHIMA, 2018). 